JEL: G34, K22, L74

University of Tokyo

Faculty of Economics

7-3-1 Hongo, Bunkyo-ku, Tokyo

FAX: 03-5841-5521; miwa@e.u-tokyo.ac.jp

Harvard Law School

Cambridge, MA 02138

FAX: 617-496-6118; ramseyer@law.harvard.edu

\title{
Who Appoints Them, What Do they Do? Evidence on Outside Directors from Japan
}

\author{
by Yoshiro Miwa and J. Mark Ramseyer*
}

\begin{abstract}
Although reformers often claim Japanese firms appoint inefficiently few outside directors, the logic of market competition suggests otherwise. Given the competitive product, service, and capital markets in Japan, the firms that survive should disproportionately be firms that tend to appoint boards approaching their firm-specifically optimal structure. The resulting debate thus suggests a test: if Japanese firms do maintain suboptimal numbers of outsiders, then those with more outsiders should outperform those with fewer; if market constraints instead drive them toward their firm-specific optimum, then firm characteristics may determine board structure, but firm performance should show no observable relation to that structure.

To explore the issue, we assemble data on the 1,000 largest exchange-listed Japanese firms from 1986-94. We first ask which firms tend to appoint which outsiders to their boards, and find the appointments decidedly non-random. Firms appoint directors from the banking industry when they borrow heavily, when they have fewer mortgageable assets, or when they are themselves in the service and finance industry. They appoint retired government bureaucrats when they are in construction and sell a large fraction of their output to government agencies. And they appoint other retired business executives when they have a dominant parent corporation or when they are in the construction industry and sell heavily to the private sector.

Coupling OLS regressions with two-stage estimates on a subset of the data, we then ask whether the firms with more outside directors outperform those with fewer. They do not. Obviously, one cannot draw solid conclusions from the absence of significant results. Yet the regressions do suggest -- exactly as the logic of market competition predicts -- that board composition is endogenous: firms choose boards appropriate to them. Given that the composition does not change from the thriving 1980s to the depressed 1990s, optimal board structure also seems not (at least by the observable indices) to depend on the macro-economic environment.
\end{abstract}

* Professor of Economics, University of Tokyo, and Mitsubishi Professor of Japanese Legal Studies, Harvard University, respectively. We gratefully acknowledge the helpful comments and suggestions from Stephen Bainbridge, John de Figueiredo, Jeffrey Gordon, Daniel Ho, John Lott, Toshihiro Matsumura, Johannes Moenius, Randall Morck, Yasuhiro Omori, Robert Pozen, Eric Rasmusen, Roberta Romano, David Sneider, William Stuntz, Joel Trachtman, Mark West, Noriyuki Yanagawa, several anonymous referees, and workshop participants at Harvard University, Indiana University, the Japanese Law \& Economics Association, Nagashima, Ohno \& Tsunematsu, the National Bureau of Economic Research, the University of Pennsylvania, the University of Tokyo, and Waseda University. We received financial assistance from the Center for International Research on the Japanese Economy and the Business Law Center at the University of Tokyo, and the John M. Olin Program in Law, Economics \& Business at the Harvard Law School. 
Persistently, reformers claim that firms should increase the outside directors they name to the board. If they will not appoint more outsiders on their own, the law should mandate the increase. Occasionally, scholars echo the refrain. Directors monitor senior managers for shareholders, they explain. Unless independent from those managers, they will not aggressively monitor. Unless they take the job from a career beyond the firm, they will not be independent. If a firm hopes to protect its shareholders from its managers, it simply must name more outsiders to its board.

Stated so flatly, of course, the claim misses the tradeoffs. What outsiders offer in independence, they sacrifice in expertise. The more independent they be, the less they know about the firm. In turn, the significance of that tradeoff will vary by firm. At some firms, independence will be crucial, and a broad business background may be all the expertise a director needs. At others, no amount of independence will help a director who does not know the details of the firm's business.

If boards matter, then the logic of market competition suggests that firms should tend to appoint outsiders at levels that approach their firm-specific optimum. To this logic, the BerleMeans' separation of ownership from control is beside the point. For at root, Berle and Means simply proposed an empirically testable hypothesis about the magnitude of the agency slack in the owner-controller relationship. Ultimately, it is the Japanese variant of that hypothesis that we test below.

Whether in Japan or in the U.S., most firms sell their output into competitive industries, buy their supplies from competitive sellers, and raise their funds on competitive capital markets. Facing the inevitable market constraints, those that adopt more efficient governance structures should have higher odds of survival. Berle-Means or no, in equilibrium firms should move toward their firm-specifically optimal governance structures or die. In equilibrium, those firms that survive should tend to approach the number and types of outside directors they need, and no more.

Unfortunately for the researcher, the solicitude many American legislators and judges show toward shareholder claims (usually meritless claims -- as Romano, 1991, shows) obscures this market dynamic in the U.S. A New York Stock Exchange (NYSE)-listed firm without outside directors is a firm begging for a shareholder suit, bad governance or good. In this legal environment, outside directors buy protection. Absent such directors, a U.S. firm can defend against self-dealing claims only at enormous expense. By routing its major business decisions past outside directors, however, it can dramatically lower the costs it incurs in defending against such claims (Bainbridge, 2002, pp. 270-71; Clark, 1986, pp. 166-68). Reasonably enough, listed firms in the U.S. have responded to this threat of litigation by appointing majority-outside boards. As a result, however, they no longer offer the dispersion in the data necessary to study any other roles outsiders may perform at a firm.

By exploring the place of outside directors in Japan, we examine the function such directors can play in a world without this litigation-related bias. Japanese courts have never allowed classaction suits, and until the early 1990s maintained filing fees that effectively barred derivative suits as well. By examining the appointment of outside directors there, we thus do three things. First, we explore the determinants of board composition unrelated to shareholder litigation: in a world largely without derivative and shareholder class-action suits, which firms find what kind of outside directors attractive? Second, we ask how endogenous board structure is: how forcefully does 
market competition drive firms toward their firm-specific optimum? Finally, by comparing the relation between board composition and firm performance in the late 1980s and early 1990s, we ask whether the optimal board composition depends on the macro-economic environment: do boards that facilitate high performance levels in boom times do so during recessions?

We examine the outside directors at the largest exchange-listed Japanese firms -- the approximately 1,000 firms listed on Section 1 of the Tokyo Stock Exchange (TSE) in the late 1980s and early 1990s. This is a much larger dataset than that used in other extant studies of Japanese board composition. We find: (a) that bankers tend to serve on the boards of smaller firms, more heavily leveraged firms, and firms without a large stock of mortgageable assets; (b) that retired government bureaucrats disproportionately serve on the boards of construction firms specializing in public-sector civil-engineering projects; and (c) that outside business executives primarily serve on the boards either of firms in which the executive's own firm owns a large equity stake or of construction firms specializing in large business-sector projects.

Consistent with competitive market pressures toward firm-specifically optimal patterns of board composition, we find no robust association between observable indices of board composition and firm performance. The statement holds whether we use OLS or two-stage least squares (2SLS) specifications. Consistent with the lack of any tie between optimal board composition and the macro-economic environment, we also find that this lack of association holds both for the late 1980s and for the early 1990s -- despite the similar fraction of outside directors during the two periods.

Obviously, our results do not generalize to worlds without competitive capital, product, or input markets (possibly the case in some sectors of transitional Russia, for example; see Black, 2001). Provided firms face serious market constraints, however, our logic should apply across national boundaries. Although we offer no data from other countries, we know of no reason to expect different results in other competitive market economies.

Obviously, too, the absence of statistically significant results never proves a hypothesis. Nonetheless, that absence follows logically from many of the most fundamental implications of market competition. If product, service, and capital markets clear, for example, firms will earn only a market return on their investments. Precisely because they will earn no supra-competitive returns, the empiricist will rarely observe statistically significant results. Similarly, if capital markets impound information rapidly, investors will not outperform the market. Precisely because they will earn no more than a market return, the empiricist will again generally obtain no significant results (Fama, 1998). At root, our hypothesis about outside directors claims no more and no less: markets work effectively.

Although the debate over board composition raises issues common to other debates over corporate governance, details matter. The market processes that constrain the board appointments a firm can make, for instance, need not constrain the options it faces on other governance choices (see, e.g., Gompers, Ishii \& Metrick, 2003; Black, 2001; Black, Jang \& Kim, 2003). For that reason among others, in this article we focus only on board composition. Except as expressly noted otherwise, we take no position on other governance issues.

We begin by reviewing the literature on board composition. (Section I). We explain our data set and variables (Section II). We then ask which firms appoint what kinds of directors (Section III.A.), and what observable effect these directors have on firm performance (Section III.B.).

\section{Outside Directors -- The Literature}




\section{A. The Reformist Impulse:}

Routinely, public intellectuals praise outside directors. Directors work as agents for shareholders, they reason. As agents, they police managers. If themselves "company men," they lack the independence they need adequately to police. Far better to require that firms appoint men and women not subject to the pressures that come from a lifetime at the firm.

Among the activists, several public-sector retirement plans have been among the most aggressive. By the late 1990s, CalPERS (1998) claimed a "substantial majority" of board members should be independent. TIAA-CREF followed (2000), and traditionalist organizations increasingly acquiesced. Wrote the Business Roundtable (1999, p. 10) in 1999:

It is important for the board of a large publicly owned corporation to have a substantial degree of independence from management. Accordingly, a substantial majority of the directors of such a corporation should be outside (non-management) directors.

By mid-2002, the New York Stock Exchange (NYSE, 2002, p. 2) proposed to require that "[i]ndependent directors . . . comprise a majority of a company's board." And by the end of the year, the Sarbanes-Oxley bill had added to those developments its own list of required governance changes (Cunningham, 2003).

In fact, most large U.S. firms already named outsiders to the board anyway. According to Herman (1981, p. 35), the fraction of manufacturing firms with a majority of outsiders "rose from 50 percent in 1938, to 61 percent in 1961, to 71 percent in 1972, to 83 percent in 1976." By 1973 the median large manufacturing firm had only 40 percent inside directors, and by 1988 that figure had fallen to a quarter (id.; Agrawal and Knoeber, 2001, p. 181).

Many prominent Japanese champion the same agenda. Take the "Corporate Governance Forum" headed by a university president and well-known legal scholar. Declares the Forum (Japan Corporate Governance Forum, 1998): "a majority of the board of directors should be composed of outside directors." Politicians propose legislation that would require outside directors. And through avenues like the American Chamber of Commerce in Japan, foreign institutions like CalPERS now routinely list outside directors among the changes they demand of Japan.

Western observers of Japan tend to repeat these observations. Dore (2000, p. 79), for instance, dismisses Japanese boards as "an 'insider system' over which shareholders exercise little monitoring control." Ahmadjian (2001) asserts they "rarely play a supervisory role," few are outsiders, and "many outsiders are not independent." And quoting a U.K. study, Monks and Minow (1995, p. 272) insist that Japanese boards "represent the interests of the company and its employees" rather than "the interests of shareholders."

\section{B. The Economic Logic:}

1. Introduction. -- In truth, the reformists raise their own questions. As noted earlier, what outsiders potentially contribute in independence from managers, they sacrifice in camaraderie and knowledge about the firm (Fama and Jensen, 1983; Klein, 1998). Although in some firms the former may outweigh the latter, in others it will not.

More basically, those firms that survive should disproportionately have boards that work well for them. Most firms in advanced capitalist countries raise funds, buy labor and supplies, and sell goods and services in competitive markets. As a result, those that survive should disproportionately be those with reasonably appropriate governance mechanisms -- firms whose boards either could not make a difference, or already approach their firm-specific optimum. ${ }^{1}$

${ }^{1}$ On competition in the postwar Japanese capital market, see Miwa and Ramseyer (2004a); on the pre-war capital market, see Miwa and Ramseyer (2002a). 
2. Ownership and performance. -- Ownership concentration patterns in Japan illustrate the potential impact of market competition on firm structure. In the decades since Berle and Means, scholars had claimed that the dispersed shareholdings at the large U.S. firms let managers ignore shareholder welfare. Demsetz and Lehn (1985), however, found the claim implausible. Firms that raise their funds on competitive capital markets and sell their output on competitive product and service markets, they reasoned, should choose ownership patterns close to their firm-specific optimum or disappear. If so, then any attempt to regress shareholder returns on ownership structure would yield insignificant results -- and so Demsetz and Lehn found.

Elsewhere, we use data on the 1947 American-mandated zaibatsu dissolution (Miwa and Ramseyer, 2003a) to illustrate the way competitive product, service, and capital markets have constrained Japanese ownership structures. Initially, those firms subject to the dissolution -- the firms forced by the Americans to adopt ownership structures other than what had prevailed in the market -- earned lower profits than competitors not subject to the dissolution. By 1958, however, that effect had disappeared. Within a decade, competition in product, input, and capital markets had forced firms to shift to their firm-specifically appropriate ownership patterns or disappear. As the firms subject to the American-mandated dissolution re-structured their ownership, the earlier observable relation between ownership structure and profitability vanished. ${ }^{2}$

Although some scholars dispute Demsetz and Lehn's claim that ownership is endogenous to performance (e.g., Morck, Shleifer and Vishny, 1988; Holderness, Kroszner and Sheehan, 1999), they introduce their own theoretical puzzle: why? Why, as Jensen and Warner (1988) put it, would "concentration [not be] chosen to maximize firm value"? In any event, even in their studies the observable tie between ownership and performance appears only haphazardly and usually only in non-linear specifications. Conclude Himmelberg, Hubbard and Palia (1999, p. 354), once one controls or firm-specific differences in contracting environments, the basic endogeneity reappears: "changes in managerial ownership levels have no statistically significant effect on Q."

3. Boards and performance. -- The Demsetz-Lehn logic transfers straightforwardly from ownership concentration to board composition. Perhaps at some firms investors will want outsiders who protect against insider misbehavior. Perhaps at others they will want the sophistication and cohesion that an all-inside board brings, and use other means to monitor and constrain their managers. In either case, shareholders will want directors who pursue strategies aligned with their (the shareholders') own interests. Given market pressures, managers determined to protect their jobs should thus tend to propose to their shareholders board slates that fit the firm's needs. Given market pressures, the firms without outsiders should therefore tend to be those where outsiders would bring few gains. Because firms will appoint boards that approach their firm-specific optimum, board composition should bear no observable relation to firm performance. ${ }^{3}$

\footnotetext{
${ }^{2}$ As an exogenous shock, the American-mandated dissolution of the existing ownership equilibrium created a natural experiment to study the effect of ownership on performance. Unfortunately, we know of no analogous shock to postwar board composition in Japan, and thus cannot perform a similar experiment regarding board composition. Over time, however, we do predict that the judicial decision in the early 1990s to facilitate derivative litigation (see West, 2001) may (for reasons outlined in the U.S. context) lead more Japanese firms to adopt majority outsider boards as well.

${ }^{3}$ This endogeneity to board composition is central to such econometric studies as Hutchinson (2002); Agrawal and Knoeber (1996); Bathala and Rao (1995); Beatty and Zajac (1994).
} 
As with ownership concentration, some studies do find the contrary. Regressing performance on outsider board membership, for example, some scholars find a positive association. Others, however, find a negative. ${ }^{4}$ And most literature reviews (e.g., Bhagat and Black,1999; Hermalin and Weisbach, forthcoming; Romano, 1996, 2001;) find no relationship between observed performance and board composition at all. After a "meta-analytic" study of the results, Dalton, et al. (1998, p. 278), conclude that "board composition has virtually no effect on firm performance." "No matter what variable is used to measure performance," writes Romano (1996, p. 287), "virtually all studies find that there is no significant relation between performance and board composition."

\section{Misconceptions:}

Before examining the data, table several common misunderstandings about Japanese corporate governance. First, the Japanese equity market is not inactive. Japanese firms raise not just debt but equity, and raise the two in about the same proportions as U.S. firms. When observers claim Japanese firms are more heavily levered, they primarily capture accounting differences. Corrected for those differences, writes Stewart Myers (2001, p. 83), U.S. firms have a bookdebt/asset ratio of 33 percent where Japanese firms have 37 percent. U.S. firms have a marketdebt/asset ratio of 23 percent where Japanese firms have 17. Even the widely cited restrictions on the bond market were porous (Miwa and Ramseyer, 2004a), and the equity market (despite claims about restrictiveness -- e.g., Weinstein and Yafeh, 1998, p. 636; Milhaupt and West, 2000, p. 61) faced fewer limitations still.

Second, Japanese managers do not promote employee welfare over shareholder returns. Instead, Japanese firms maintain incentives structured directly to induce their managers to augment shareholder gains. Abe (1997), Kaplan (1994), and Kaplan and Minton (1994), for instance, all find top executive tenure in Japan tied to firm performance. All else equal, executives who earn shareholders large returns do better. Those who fail to earn them do worse.

Third, Japanese executives do not ignore corporate-control-market incentives. Instead, they face a thriving market in corporate control. Although tender offers are rare, they have long been possible. For managerial incentives, of course, what matters is not the number of takeovers but the potential for them. Indeed, if potential raiders could acquire a firm readily enough, in equilibrium they seldom would -- for managers would manage in ways that did not make themselves a target (a point missed in, e.g., Milhaupt and West, 2003). What is more, in Japan mergers and asset sales are common. In 1994, Japanese firms engineered 1,917 mergers and 1,153 sales of all or substantially all their assets (Kosei, 1994, p. 181). Crucially, mergers and asset sales move productive assets to higher valued uses as effectively as tender offers.

Last, the Japanese government has not used regulation to soften the constraints imposed by the bank debt market. Although for years it purported to ration funds, for most of the last halfcentury firms raised their money in competitive markets at competitive rates. The bank loan restrictions it imposed simply did not bind. Even as early as the 1970s, firms borrowed at market rates (Miwa and Ramseyer, 2004a).

II. The Data

A. Introduction:

${ }^{4}$ Positive effects: e.g., Black, Jang and Kim (2003); Baysinger and Butler (1985); Ezzamel and Watson (1993); Brickley and James (1987); Mayers, Shivdasani and Smith (1997). Negative effects: e.g., Kesner (1987); Agrawal and Knoeber (1996); Klein (1998); Vance (1978). 
To study board appointments in Japan, we assemble information on all non-bank firms listed on Section 1 of the Tokyo Stock Exchange (the largest firms). We collect financial data from 1986 to 1994, and board composition data in 1985, 1990, and 1995. We then use these data to determine which firms appointed what kinds of directors (Section III.A.), and what observable effect those directors had on firm performance (Section III.B.). Both because of the idiosyncratic regulatory structures involved and because bank accounting data differ substantially from accounting data in other industries, we do not pool banks with manufacturing firms. Instead, we explore the connection between board composition and profitability among banks in Miwa and Ramseyer (2003b), and exclude banks from this data set. We ignore a firm's purported keiretsu affiliation for reasons explained in Miwa and Ramseyer (2002b).

B. Sources:

We take our basic financial data from the Nikkei NEEDS data base. We then add several additional variables: from the Kabushiki toshi shueki ritsu (Nihon shoken) we gather shareholder returns; from work by Asako, Kunimori, and others (1997), we obtain Tobin's Q; and from the Kigyo keiretsu soran (Toyo keizai) we collect information on board composition and the presence of a dominant shareholder.

C. Variables:

With these data, we construct the following variables:

1. Performance variables. --

Q: Tobin's Q for TSE-listed manufacturing firms (not the whole data set), averaged over 1986-90 and 1990-94. ${ }^{5}$

ROI: Total annual shareholder returns on investment (annual rate of appreciation in stock price plus dividends received) for 1985-90 and 1990-95.

Operating-Income/TA: The ratio of a firm's operating income (\#95 of the Nikkei NEEDS data base) to total assets (\#89) for each year, averaged over 1986-90 and 1990-94.

Ordinary-Income/Eq: The ratio of a firm's ordinary income (operating plus nonoperating income, less non-operating expenses [such as interest]; \#110) to equity (\#78) for each year, averaged over 1986-90 and 1990-94.

Growth: The annual growth rate, in percentage, of a firm's total assets, averaged over 1986-90 and 1990-94.

2. Board composition variables. -- As of 1985,1990 , and $1995:^{6}$

Past Bankers: The number of directors on the board with a past career at a bank.

Past Other Firm: The number of directors on the board with a past career at another firm (other than a bank).

Past Bureaucrat: The number of directors on the board with a past career in government.

${ }^{5} \mathrm{Q}$ is "multiple Q," given the consideration which the compilers gave to the impact of real estate prices on corporate performance. See Asako, et al. (1997).

${ }^{6}$ That is, in most cases, the directors chosen at the first shareholders' general meeting after the 1985, 1990, and 1995 fiscal years. Because most firms hold their meetings in June and have an April-March fiscal year, the 1985 directors would be those selected in June 1986, after the end of fiscal 1985 (April 1985-March 1986). 
Concurrent Banker: The number of directors on the board with a concurrent position at a bank.

Concurrent Other Firm: The number of directors on the board with a concurrent position at another firm (other than a bank).

Total Outside Directors: The sum of the above directors.

Majority Outside Directors: 1 if outside directors constituted 50 percent or more of all directors; 0 otherwise

Although shareholders themselves elect only the members of the board (the torishimari yaku), those directors usually select a subset of themselves to handle routine issues. These selected directors (jomu, senmu, and various corporate officers; we translate the term as "executive directors") enjoy no special legal status (Miwa, 1998, pp. 104-11). Because some observers claim that the identity of these executive directors matters more than that of the others, we report results both for executive director composition and for board composition more generally.

Obviously, one could define an "outsider" in many ways other than the way we defined it here. We nonetheless choose these categories because they reflect the principal debates over Japanese corporate governance. Bankers lie central to the elaborate economic literature on main bank monitoring (see Miwa and Ramseyer, 2003c, 2003d). Retired bureaucrats have similarly generated a massive literature (including two entire English-language books in the last two years alone; see van Rixtel, 2002, and Colignon and Usui, 2003). And directors from "other firms" represent the men and women Americans traditionally consider "outside directors."

\section{Control variables. --}

Board Size: The number of directors (or executive directors) at a firm in 1985, 1990, and 1995. ${ }^{7}$

Dominant S/h: 1 if any shareholder held 25 percent or more of the firm's stock in 1985, 1990, or 1995; 0 otherwise.

Volatility: The variance of the ratio of a firm's operating income (\#95) to total assets (\#89) over 1986-90 and 1990-94.

Total Assets: The average total assets of a firm (\#89) over 1986-90 and 1990-94, in million yen.

Tangible Assets/TA: The average ratio of a firm's tangible assets (\#21) to total assets (\#89) over 1986-90 and 1990-94.

Sales/TA: A firm's average sales (\#90) over 1986-90 and 1990-94, divided by its average total assets (\#89) over 1986-90 and 1990-94.

Bank Debt/TA: The sum of a firm's short- (\#46) and long-term (\#47, 63) borrowings divided by its total assets (\#89), averaged over 1986-90 and 1990-94.

Industry dummies: Dummy variables for affiliation in the construction, trade, service and finance (but excluding banks), transportation (and utilities and real estate), light industry, chemical, machinery, and metals industries.

We include selected summary statistics in Tables 1-3.

[Include Table 1 about here.]

[Include Table 2 about here.]

\footnotetext{
${ }^{7}$ For this and other director variables, the data cover those directors who, after serving in management elsewhere, are named to the board within 3-4 years of joining a given firm. The numbers include statutory auditors (kansayaku), on the grounds that Japanese discussions of "yakuin" (colloquially translated as "directors") typically include the kansayaku.
} 
[Include Table 3 about here.]

\section{The Regressions:}

We first explore the determinants of outside director appointments. Toward that end, we regress the number of outside directors of each type (both directors at any rank and executive directors) in 1985 and 1990 on firm financials and industry affiliation. Given that the dependent variable involves count data, we use Poisson (but with z-statistics calculated using the Huber-White sandwich estimator of variance). Because rational firms will choose their governance structure with an eye to their anticipated needs, we suggest readers consult the regressions coupling 1986-90 financial data with 1985 board composition (Table 4, Panel I), and 1990-94 data with 1990 composition (Pan. III). Given the endogeneity that this procedure raises, however, we also include regressions pairing 1990 board composition with 1986-90 financials (Pan. II), and 1995 board composition with 1990-94 financials (Pan. IV). Both sets yield similar results.

Several readers suggested that the crucial distinction depended not on the number of outsiders a firm had on a board but on whether it had any. To enable readers to explore this issue, we also calculate probit estimates of the appointment of any outsider to the board (Table 5). In each case, the dependent variable is a dummy variable equal to 1 if a firm had any directors of a given type.

Last, we study the effect of board composition on firm performance. We do this by regressing performance in the two periods on (i) the number of outside directors of each type, (ii) various firm financials, and (iii) industry dummies. To check for robustness, we use several distinct measures of performance, and 2SLS as well as OLS.

\section{Outside Directors -- the Discussion}

A. Who Appoints Them?

1. Introduction. -- Consider two preliminary observations. First, Japanese boards are big. At our 1,029 firms on Section 1 of the TSE in 1985, the boards ranged from 6 directors to 54, with a median of 18 and a mean of 19.5; the executive directors ranged from 1 member to 32, with a median of 7 and a mean of about 8 (Table 1, Panel A.1). By contrast, large U.S. manufacturing firms in 1988 had a mean board of about $12 .^{8}$

Second, the majority of Japanese directors were "insiders." Among our firms in 1985, 14 of the mean 19 directors were career firm employees and 6 of the mean 8 executive directors were (Tab. 1, Pan. A.1). Put another way, at the mean 1985 firm 26 percent of the directors and 27 percent of the executive directors had either past or concurrent appointments at other institutions (Tab. 1, Pan. F). The mean varied widely by industry: from fewer than 3 outside directors in light industry, to nearly 9 in service \& finance (Tab. 1, Pan. C). Those firms with bigger boards did have more outsiders, but only modestly more (Tab. 1, Pan. B)

Outsiders did not dominate Japanese firms, but neither were they absent. On the one hand, only 15 percent of the firms had at least half outside directors, and 23 percent had at least half outside executive directors (Tab. 1, Pan. D.1). ${ }^{9}$ On the other, only 10 percent of the firms had no

${ }^{8}$ Agrawal and Knoeber (2001, p. 182 tab. 1). In Japan, the correlation between firm size (Total Assets) and board size (Board Size) is 0.60. This high correlation probably explains why studies examining only the very largest listed Japanese firms (e.g., Calder 1989, p. 384; Ahmadjian, 2001) find bigger boards.

${ }^{9}$ Other studies purport to show that Japanese firms have a much lower fraction of outside directors than our data. This is largely because the number of outsiders at a firm is inversely associated with firm size (Table 4), and these studies look only at the very largest listed firms. 
outsiders (Tab. 1, Pan. D). The ratios again varied by industry: only 6 percent of the firms in light industry had majority outsiders, while 51 percent of those in service \& finance did; only 2 percent of the construction firms had no outsiders while 20 percent of the light industry firms had none (Tab. 1, Pan. D). Among large U.S. manufacturing firms, nearly three-quarters were outsiders (Agrawal and Knoeber, 2001, p. 182 tab. 1).

We follow the practice in the literature on Japanese boards (e.g., Kaplan and Minton, 1994) in defining as outsiders those directors with either a past career or a concurrent career outside the firm. The former predominate. At our mean firm in 1985, 1.8 of the 19.5 directors were former executives at other firms, and 1.1 currently held such positions; 1.1 were former bankers, and 0.2 currently worked at banks; 0.5 were former government officials (a practice known as amakudari), and legal restrictions prevented current officials from holding board posts (Tab. 2, Pan. A). Of the 7.9 executive directors at the mean firm, 1.0 were former executives at firms, and 0.1 currently held such positions; 0.5 were former bankers, and 0.01 currently worked at banks; 0.3 were former government officials (Tab. 2, Pan. A).

More generally, at the mean firm 6.9 percent (and 2.1 percent of the executive directors) held concurrent posts elsewhere. At only 3 firms were such directors at least half the board, and at only 9 at least half the executive directors. None of this is required. Should they wish to do so, Japanese firms have long been free to appoint men and women who hold full-time jobs elsewhere. Notwithstanding, however, they have largely chosen to give their directors full-time positions at their own firm instead.

2. Change over time. -- Suppose that the directors a firm needs to lead it during economic booms will not necessarily lead it well during hard times. Because of the radical break in Japanese economic performance in 1990, this would imply a shift in optimal board composition. Where from 1986 to 1990 real GDP grew at about 5 percent a year, from 1991 to 1994 it grew barely 1 percent annually. Where from the NIKKEI stock index rose from 11,500 at the close of 1984 to a high of 38,900 at the end of 1989, by the close of 1994 it had fallen to 19,700 and by January 2002 had dropped below 10,000. Where the number of firms (with debt over 10 million yen) failing dropped from 17,500 in 1986 to 6,500 in 1990, by 1994 it had climbed to 14,000 and by 2001 to 19,200. The liabilities involved in the failures fell from 3.8 trillion yen in 1986 to 2 trillion in 1990, only to climb to 17 trillion by 2001 (BOJ statistics, available at www.boj.or.jp).

If optimal board composition varies by the macro-economic environment, then those directors suited to Japanese firms in the late 1980s would have been far less appropriate for the early 1990s. Necessarily, many firms that chose directors to maximize performance would have appointed different types of men and women during the two periods. Disproportionately, firms that kept their boards unchanged would have included those with inappropriate boards for at least one of the two periods.

At least by observable indices, Japanese firms did not change the types of directors they appointed. In 1985 they chose outsiders for 25.6 percent of their directors, in 1990 for 24.9 percent, and in 1995 for 25.8 percent. Of those outsiders, they consistently chose 6-7 percent from banks, 16-17 percent from other firms, and 2-3 percent from the government (Tab. 1, Pan. F). From 1985 to 1990,34 percent of the firms kept the number of outsiders they named to their boards unchanged. Sixteen percent added one outsider and 17 percent added two or more; 18 percent cut one outside director and 15 percent cut two or more. From 1990 to 1995, 29 precent made no change in the number of outside directors, 22 percent added one, and 20 percent added two or more; 16 percent cut one outsider, and 14 percent cut two or more. During both periods, the mean 
change per firm in the absolute value of the number of outside directors ranged from 1.3 to 1.4 (Tab. 1, Pan. G).

3. Former bureaucrats. -- (a) The literature. Specialists on Japan routinely argue that the Japanese government uses retired bureaucrats to influence business behavior. As Aoki (1998, $\mathrm{p}$. 299) puts it, retired bureaucrats allow a ministry to "extend its visible and invisible influence throughout its jurisdiction." This results, according to Schaede (1995, p. 316; Schaede, 1994, p. 317), in "consultative capitalism," a system "where market mechanisms are supplemented by cooperative efforts of government and business to ameliorate potential antagonism between their respective interests." In this world, claims she, "a company president is careful to attend to the advice and counsel of former ministry officials." In turn, those officials "act to coordinate and harmonize relations between business and government."

More generally, observers argue that the retired bureaucrats help the government guide the economy. Upon retirement, Schaede (1994, p. 318-19) writes, ex-bureaucrats "contribute directly to [the] alignment" of "corporate decisions with government interests." Given the confluence of widespread business regulation with such a "high number of amakudari board members," reasons she, "ex-government officials constitute an important factor in the Japanese governance structure." According to Hoshi (1998, p. 862), the ex-bureaucrat directors illustrate "the influence of the government over private firms," and give it a way "to intervene in the management if necessary." Bureaucrats allegedly exercise this influence, moreover, in economically important sectors. Claims Okimoto, MITI sends its ex-bureaucrats "to the very sectors identified as most central to the development of Japan's economy.",10

(b) The results. Although we do not purport to test the effect of the ex-bureaucrats on the enforcement of government policy, one should wonder. At root, ex-government directors are few and far between (Tables 1-2). Our 1,029 firms in 1985 had only a mean 0.5 ex-government directors and 0.3 ex-government executive directors (Tab. 2, Pan. A). Seventy-four percent of the firms had no ex-government directors at all, and 83 percent had no executive directors. What is more, few of the firms with ex-bureaucrats were in any of the industries that drove the post-war economic growth. Instead, as our Table 4 regressions of the number of ex-bureaucrats on firm characteristics show (we discuss the issue more fully in Subsection 6), they were primarily in the construction industry. ${ }^{11}$

[Insert Tables 4 and 5 about here.]

4. Bankers. -- (a) The literature. Banks play an important role in most analyses of Japanese corporate governance, and "main banks" are central to the accounts. "2 Morck, Nakamura and Shivdasani (2000, p. 540; Sheard, 1996, p. 181) declare that in Japan "corporate governance rights rest primarily with banks," and Sheard describes the banks and large shareholders as "the principal

${ }^{10}$ Okimoto (1989, p. 162). More ambiguously, Calder (1989, p. 383), claims that ex-government officials are "quite numerous" in "some strategically important sectors of the economy" -- but then gives the construction industry as an example of a "strategically important" sector.

${ }^{11}$ They were also in the banks, as we discuss in Miwa and Ramseyer (2003b).

${ }^{12}$ In their study of the 119 largest Japanese firms, Kaplan and Minton (1994) examine the relation between firm performance and executive turnover. They find that the lowest-performing firms tend to increase the number of bankers they appoint to the board. We discuss this issue in Miwa and Ramseyer, 2003c. 
agents of direct corporate governance in Japan." Japanese firms borrow heavily from banks, the story goes. Among the banks, one typically acts as the firm's "main bank." As such, it lends the firm the largest portion of its funds, and implicitly agrees to rescue it if times turn bad. ${ }^{13}$ Relevant here, as Morck, Nakamura and Shivdasani (2000, p. 540) again explain, it plays "a key corporate governance role."

According to many accounts, the main bank also implicitly agrees to monitor the firm on behalf of the firm's other creditors. Typically, big Japanese firms borrow from many banks. Because the banks would waste resources if they each monitored all firms, each implicitly agrees (in these accounts) to monitor those for which it serves as the "main bank." In Aoki's (2000, p. 79) words, the main bank becomes the firm's "exclusive" monitor. The banks, as Sheard (1994, p. 8) modeled it, are "completely diversified in their lending but . . . spread the burden of being a monitor by having each bank be responsible for monitoring [only a small fraction of] firms." As a result, "[a]1l firms are monitored but each firm is monitored by only one bank."

Consistent with these narratives, observers claim that the main bank wields power in the board room. Kester (1993, p. 70), for instance, writes that "one or more members of a typical (21member) Japanese board frequently are former executives of the company's main bank(s)." According to Monks and Minow (1995, p. 265), at large Japanese firms "outside directors usually represent major lenders." In Sheard's (1986, p. 181) account, "main banks directly exercise 'voice' by supplying managers to the board." And according to Hermalin and Weisbach (1998, p. 112), representatives of a Japanese firm's principal lender "usually serve on the company's board."

(b) The results. Several facets of the banker-director phenomenon are uncontroversial. First, directors (and executive directors) with banking bankgrounds tend to serve on the boards of firms with more bank debt (Bank Debt/TA; Table 4). Second, ex-bankers are less likely to serve on the boards of firms dominated by a major shareholder (Dominant $\mathbf{S} / \mathbf{h}$ ). Last, ex-bankers are more likely to serve on the boards of firms without a large stock of mortgageable assets (Tang Ast/TA; Tab. 4).

More problematic is the question whether bankers dominate boards. While bankers are more common than some other outside directors, about half the firms have none. Of all 1,029 firms in 1985, 47 percent had no ex-banker director, and 63 percent had no ex-banker executive director. The mean firm had 4.7 outside directors, but only 1.1 with a background at a bank (Tab. 1, Pan. A.2; Tab. 2, Pan. A). According to Cable, at the largest 100 German companies banks held 9.8 percent of all board seats; by contrast, at the largest 100 Japanese firms, ex-bankers held 5.5 percent of the board seats, and 5.9 percent of the executive board seats. ${ }^{14}$

Most of the banker-directors were ex-bankers rather than men currently working at banks. If they held their seats as a bank's agent, one would not expect them to have traded their bank job for a nominally full-time position at the firm. Instead, one would expect them to have retained their bank career. In fact, however, only 15 percent of the 1985 firms had a director with a concurrent bank position, and fewer than 1 in a 100 had an executive director with a concurrent bank post.

${ }^{13}$ The claim is false, as we demonstrate in Miwa and Ramseyer (2002c, 2003c, 2003d). See also Hayashi (2000); Hall and Weinstein (2000).

${ }^{14}$ Cable (1985, p. 119). Among all the firms in our sample, ex-banks held 5.9 percent of the directorships and 7.4 percent of the executive directorships. 
Third, banker directors tended to serve at the service and financial firms rather than the manufacturers (Tabs. 2, 4). In the service and finance industry, the mean 1985 firm had 2.4 exbank directors and 1.1 ex-bank executive directors. By contrast, in the chemical industry the mean firm had 1.2 ex-banker directors and 0.6 executive directors; in the machinery industry it had 1.0 ex-bank directors and 0.5 executive directors; and in metals it had 0.8 ex-bank directors and 0.4 executive directors (Tab. 2).

Last, while some ex-bank directors came from a firm's "main bank," many did not. More precisely, firms recruited 57 percent of their ex-bank directors from their main bank (defined as the institution that lent the firm the greatest amount of debt), and 64 percent of their ex-bank executive directors. Because the main bank is (by definition) the bank that has lent the most, if the costeffective level of monitoring rises with the amount of debt outstanding, then a main bank will necessarily have the greatest incentive to monitor -- "delegated" monitor or no. On the other hand, if its directors serve as the exclusive monitors for all other banks, only bankers from the main bank should appear on board. In fact, about half the ex-bank directors are from the main bank.

5. Non-bank outside executives. -- People and firms who invest heavily in a company will demand a mechanism by which to influence the company. Consistent with that logic, the firms that appoint the most outside business executives to the board (non-bank, non-government outside directors) are those with a dominant shareholder. On the Tokyo Stock Exchange, about a fifth of the firms have a shareholder with 25 percent or more of the stock (Dominant $\mathbf{S} / \mathbf{h}=1$; Tab. 3, Pan. B).

Firms with a dominant shareholder are more likely than others to have at least one retired outside business executive on their board. Among all TSE firms, 57 percent had such a director (45 percent had an executive director; Tab. 6, Pan. A). Among those with a dominant shareholder, however, 81 percent had such a director (78 percent had an executive director). Among all TSE firms, retired executives constituted 10.4 percent of the board (14.7 percent of the executive directors; Tab. 6, Pan. A). At those with a dominant shareholder, they constituted 24 percent (36 percent of the executive directors). The pattern parallels the appointments of executives with concurrent appointments at other firms.

Predictably, these outside directors often came from the dominant shareholder itself. Of the 1,884 retired executives from other firms serving as directors at the TSE firms, 39.3 percent were from a dominant shareholder. Of the 403 serving as executive directors, 39.9 percent were.

Our basic Table 4 regressions reflect these appointment patterns. When we regress the number of retired outside executives on various firm characteristics, the coefficient on Dominant $\mathbf{S} / \mathbf{h}$ is significant both for directors generally and for executive directors. The magnitude of Poisson regression coefficients are hard to interpret, but the OLS equivalents suggest that the presence of a dominant shareholder increases the number of such retired directors by 2.4. It increases the number of retired executive directors by 1.5, and the number of directors with concurrent posts in other firms by 1.4 .

[Insert Table 6 about here.]

6. Industry-specific effects. -- (a) Appointment patterns. Outside director appointments vary widely by industry. Disproportionately, both retired bureaucrats and retired executives work in a few industries. Indeed, disproportionately they work at the construction firms. ${ }^{15}$

${ }^{15}$ A point noted even by some of those who reach different conclusions about the hiring of ex-government officials. See, e.g., Schaede (1995, p. 309); Okimoto (1989, p. 162; Calder, 1989, p. 383; Blumenthal, 1985, p. 315). 
Bureaucrats. Take the ex-bureaucrats. Where the average TSE firm had half an exbureaucrat on its board in 1985, the average construction firm (101 firms) had 2.6 (Tab. 2, Panels A, B). Where a quarter of the TSE firms had ex-bureaucrat directors, 71 percent of the construction firms did. Where 17 percent of the TSE firms had ex-bureaucrat executive directors, 63 percent of the construction firms did. Of the 542 ex-bureaucrat directors at all TSE firms, nearly half (260 directors) were at the construction firms. Of the ex-bureaucrat executive directors, 55 percent were.

Okimoto to the contrary notwithstanding, firms in industries "central to the development of Japan's economy" did not recruit ex-bureaucrat directors. In the machinery industry in 1985, nearly 80 percent of the 275 firms had no former government officials on their board, and 90 percent had none as an executive director. In the chemical industry (156 firms), 89 percent had no government officials on their board, and 93 percent had none as a executive director. Indeed, the average machinery firm had only 0.32 ex-bureaucrats on its board, and the average chemical firm only 0.13 .

Even financial services firms were no more likely to hire ex-bureaucrats than the construction firms. Because we explore banks more fully elsewhere, we exclude them from the sample here. ${ }^{16}$ In fact, however, in 1986 only 2 of the large money center banks had a former Ministry of Finance (MoF) official as a executive director, and only 3 had any executive directors from the Bank of Japan (BoJ). Schaede's (1994, p. 290-91; see Aoki, et. al, 1994, p. 32) claim that "the CEOs of many major city banks were retired government ministry officials" is simply untrue.

The regional banks had more ex-bureaucrats than the city banks, but no more than the construction firms. Of the 56 regional banks, 48 percent had a MoF director and 50 percent a BoJ director; 36 percent had a MoF executive director and 39 percent a BoJ executive director. Replicating the construction firm ratios, 71 percent of the regional banks had either a MoF or a BoJ director, and 63 percent had either a MoF or a BoJ executive director. ${ }^{17}$ Of the 43 non-bank firms in the services and finance industry, 74 percent had no ex-bureaucrat directors, and 81 percent had no ex-bureaucrat executive directors.

The Table 4 Poisson regressions reflect this concentration of government officials in construction: for both directors and executive directors, the coefficient on construction industry membership is a statistically strongly significant predictor of ex-bureaucrat appointments. According to analogous unreported OLS regressions, the coefficient on construction industry membership is 1.9. Consistent with the Table 2 data, the average 1985 construction firm had 2 more ex-bureaucrats on its board than the other firms.

Executives. Outside business executives too disproportionately worked at the construction firms. Consider again our Table 4 regressions. For both all directors and executive directors, the coefficient on construction industry affiliation is larger and statistically more significant than on

\footnotetext{
${ }^{16}$ Miwa and Ramseyer (2004b). As defined here, the industry includes service firms not providing financial services.

${ }^{17}$ Elsewhere, Schaede (1995, p. 310) writes (apparently a claim diametrically opposed to that in Schaede (1994)) that "most firms" in the banking, investment banking, and insurance industries "do not hire OBs [exgovernment officials] at all." In fact, as both the discussion in the text (for banks) and Tables 2 and 4 (for other financial services firms) show, this claim too is false: firms in these industries are at least as likely to hire them than as the average firm in the sample as a whole.
} 
any other industry dummy. All told, 18.7 percent of the retired business executives served at construction firms in 1985, and among the executive directors 19.5 percent did.

(b) Revenue effects. In the construction industry, board appointments reflect expected revenues. ${ }^{18}$ Among the construction firms, those that focused on public-sector projects were most likely to appoint ex-bureaucrats. Those that focused on large private-sector projects may have been most likely to appoint retired executives from other firms. To show this, we create two new variables: ${ }^{19}$

Construction Rev: the percentage of a firm's revenues generated by construction projects (other than prefabricated housing) for 1985.

Civil Eng Rev: the percentage of a firm's revenues generated by civil-engineering projects for 1985.

The two variables roughly proxy for a firm's dependence on business-sector projects and government projects, respectively. Construction Rev represents revenues from private-sector office construction, together with occasional government projects. Civil Eng Rev almost exclusively represents revenues from government projects like road construction. The correlation coefficient for the two is -.23 .

In Poisson regressions (A) and (B) of Table 7 we regress (a) the number of directors (or executive directors) in 1985 who had retired from government posts on (b) Construction Rev and Civil Eng Rev. In Regressions (C) and (D), we do the same for the number of directors (or executive directors) who had retired from other firms.

The regressions generate three straightforward results. First, the more heavily a firm relies on civil-engineering projects, the more ex-bureaucrats it names to directorships and executive directorships. Increased construction revenues also correlate with ex-bureaucrat directors, but the effect is smaller. Second, the less a firm relies on civil-engineering projects, the more retired business executives (sometimes from its principal customers) it names to its board. Higher construction revenues may also predict the appointment of such retired business executives, though the coefficients are not statistically significant.

Third, firms with a dominant (25 percent or more) shareholder appoint more outside executives. Indeed, the presence of a dominant shareholder increases the number of retired outside executives on the board by more than 3 , and the number of executive directors by more than 2 . As the summary statistics in Table 6 show, the pattern applies not just to executives retired from other firms but to those holding concurrent appointments at other firms.

[Insert Table 7 about here.]

(c) The logic. -- Confronted with evidence that construction firms hire retired government bureaucrats, observers typically assume corruption. Given the bid-rigging scandals on publicsector projects, the assumption is superficially plausible enough. Journalists like van Wolferen seem to argue that firms appoint bureaucrats to the board as a form of deferred compensation for colluding on past bids. Schaede claims as well that they appoint them to facilitate future bribes. The "industry is characterized by secret bidding procedures," she writes, "where private firms collude to predetermine both the winner of the auction and the price this winner is to bid." In this context, a former bureaucrat "can be invaluable in acquiring prior information on planned public

\footnotetext{
${ }^{18}$ For an analogous phenomenon in the U.S., see Agrawal and Knoeber (2001).

${ }^{19}$ The data are from Toyo keizai, Kaisha shikiho.
} 
projects and government price ceilings on these projects." Concludes Schaede, the ex-bureaucrat facilitates "access to price and project information in the bid-rigging process.",

Despite its appeal, the argument is problematic. In Japan as in the U.S., bid-rigging is a serious crime. When in 1976 a mayor's campaign staffer solicited funds from a contractor in exchange for favorable treatment on a city housing project bid, he found himself prosecuted and convicted for bribery. ${ }^{21}$ When in 1991 a construction firm executive director bribed a mayor for a contract for its new sports facility, he found himself sentenced to two years in prison (suspended), and civilly liable to the firm besides. ${ }^{22}$ And when a director at a real estate development firm bribed a prefectural governor for regulatory clearance and favorable treatment on a bid, a court convicted them both: 2 years in prison for the governor, and 2-1/2 for the director, neither term suspended. ${ }^{23}$

Although heavy penalties may not cut crime rates to 0 , usually they will both reduce it and induce criminals to adopt tactics that are harder to detect. The high Japanese penalties for bidrigging may not eliminate the crime, but they ought to induce those firms determined to rig the process to negotiate and pay their bribes covertly. Yet to hire ex-bureaucrats either to negotiate the crime or to compensate co-conspirators is nothing if not flagrantly visible.

Ex-bureaucrats probably would not help rig many bids anyway. Because of the high penalties, most bureaucrats will not rig bids unless they know well the person propositioning them. A Prefecture B official will not likely agree to the crime just because the man approaching him once worked for the Ministry of Construction (MoC). Even less will he much care whether the man once worked for prefecture A. Perhaps a retired bureaucrat from city $\mathrm{C}$ will help rig a bid with city $\mathrm{C}$. He will hardly help cheat anywhere else. The retired bureaucrats at the construction firms, however, come from a wide range of national and local government offices.

Crucially, the $\mathrm{MoC}$ does not auction public sector projects nation-wide, and neither does anyone else. Instead, for any given project the government unit involved solicits its own bids. Cities solicit bids for city projects, and prefectures solicit those for their own. The national government itself solicits less than 12 percent of all public-sector projects. As Table 8 shows, prefectural and municipal governments each solicit another 30 percent, and assorted public entities solicit the rest.

Table 7 instead suggests a more mundane explanation for the hiring patterns (one consistent with the data Agrawal and Knoeber, 2001, locate for the U.S.): construction firms appoint board members who will help them identify the services their principal customers want to buy. If they sell heavily to the public sector, they appoint men with experience in government. If they sell heavily to the private sector, they appoint executives with experience in business. ${ }^{24}$

Manufacturing firms need to learn about customer preferences too, of course, but for them it is information they can cheaply obtain elsewhere. If a firm sells large quantities of standardized products (tractors, DVD players) into the general retail market, it can learn buyer preferences by

${ }^{20}$ van Wolferen (1989, p. 118); Schaede (1995, p. 309). The claims also appear in Woodall (1996, pp. 40-41, 70-71). Analogous arguments about the banking industry appear in Horiuchi and Shimizu (2001) and van Rixtel and Hassink (2002).

${ }^{21}$ Japan v. [No name given], 1199 Hanrei jiho 157 (Sup. Ct. June 27, 1987).

${ }^{22}$ Matsumaru v. Otsuru, 1518 Hanrei jiho 4 (Tokyo D. Ct. Dec. 22, 1994).

${ }^{23}$ Japan v. Kono, 1611 Hanrei jiho 36 (Tokyo D. Ct. March 21, 1997).

24 Obviously, this is consistent with the use of directors to obtain "access." Our quarrel with the literature instead concerns the claim that construction firms use board composition to facilitate bid-rigging. 
surveying customers or auditing sales patterns. Kubota need not appoint a farmer to its board to learn which plow its customers want to buy. It can simply watch which plows sell.

By contrast, construction firms sell small numbers of non-standardized service packages (the construction of airports or office towers) to specific customers. To sell successfully, they need to tailor the packages they offer to buyer preferences. Yet surveys and sales audits will only haphazardly enable them to do that. To tailor their packages, they instead recruit men with a lifetime of experience at the types of organizations to which they sell.

[Insert Table 8 about here.]

\section{B. What Do They Do?}

1. Introduction. -- For all the reasons Demsetz and Lehn explained, disproportionately the firms that survive in competitive capital, product, and input markets should be firms with governance mechanisms approaching their firm-specific optimum. Given those market constraints, any regression of firm performance on firm governance should yield insignificant results. Obviously, insignificant results will not prove that the firms have reached their optimal structure. Insignificant results never do.

Instead, what regressing firm performance on governance structures will do is to check whether firms maintain observably inefficient structures. If the conventional accounts are right, they do: many Japanese firms maintain inefficiently low levels of outside directors. And if so, then the firms with more outside directors should out-perform the firms with fewer.

For the seventy years since Berle-Means, corporate reformers have claimed that the modern separation of ownership from control keeps firms from maximizing shareholder returns. Yet suppose that outside directors would mitigate the negative consequences of that separation, and help shareholders earn higher returns. Given that most firms do appoint at least some outside directors, managers seem not to make outside appointments impossible. If so, however, then those firms that do surmount the hypothesized managerial opposition to outsiders should earn higher returns than those that do not, even under OLS specifications.

2. The exercise. -- In Table 10, we report the results of regressing firm performance on board composition through OLS, and in Table 11 we do the same for a subset of our sample through 2SLS. To check for robustness, we use five distinct indices of firm performance: Tobin's $\mathrm{Q}$ (Q; available only for the manufacturing firms), shareholder returns (ROI), two measures of accounting profitability (Operating-Inc/TA and Ordinary-Inc/Equity), and the growth rate of the firm's asset base (Growth). We include ROI because it serves as an obvious metric of firm performance. Given that stock prices should incorporate the anticipated effect of board composition, however, we caution readers against expecting significant coeffficients. We include Growth because of the widespread claims that Japanese firms pursue growth rather than profits or shareholder returns. Here too, however, we urge caution: the claims about growth-maximizing Japanese firms have no theoretical rationale, and to date lack any serious empirical support.

With each performance index, we separately examine the effect of board composition on performance for the 1986-90 period (Table 10, Panel I) and 1990-94 (Pan. II). We examine both total board composition (Pans. I.A., II.A.) and the composition of the executive board (Pans. I.B., II.B.). Within each subpanel, we then examine the effect (1) of the number of outside directors from each of several categories, (2) of the fraction of outside directors from each category, (3) of dummy variables indicating the presence of any directors from each category, (4) of the total number of outside directors, and (5) of a dummy variable indicating the presence of a majority of 
outside directions. In each regression, we add financial variables and industry affiliation dummies. For expositional economy, we report the coefficients on these additional variables only in Panels I.A.1. and II.A.1.

We break the data in 1990 because of the dramatic economic shift we detailed earlier. If competition does push firms toward their optimal board structure, then the 1990 break in Japanese performance lets us ask whether that optimum varies by economic environment. As noted above, Japanese firms did not change the types of directors they appointed from 1985 to 1995 . Yet suppose the optimal board structure depended on macroeconomic health. Even if board composition had no observable impact on performance in the 1980s, it might plausibly have had such impact in the early 1990s. If good board structure is not environment-specific, however, then that structure would not visibly have affected performance in either period.

Before turning to the regressions, consider the summary statistics in Table 9. At least by these simple indices, outside directors are not observably associated with higher performance. In 1986-90, firms with Majority Outside Directors had higher Tobin's Qs, shareholder ROI, and asset Growth, but lower Ordinary-Income/Eq and (relative to those with no outsiders) lower Operating-Income/TA. By 1990-94, other than Growth and Operating-Income/TA, they underperformed the other firms on every index.

[Insert Tables 9 and 10 about here.]

3. OLS, 1986-90, total board composition. -- Regression results largely confirm what the logic of market competition predicts: 1985 board composition has no observable effect on 1986-90 performance, and neither does 1990 composition observably affect 1990-94 preformance. Even when statistically significant, the results are not robust to alternative performance measures.

Take the relation between board size and performance. A few scholars have found that U.S. firms with big boards outperform those with small. For that result, they usually propose only theoretically dubious explanations. And our own Table 10 Panel I.A. results illustrate the sensitivity such atheoretic inquiries show to quirks in the data: just as large boards are associated with significantly higher Tobin's $\mathbf{Q}$, they seem to be associated with lower Growth rates. In the later period (Pan. II.A.1.), large boards are again associated with higher $\mathbf{Q}$, but now with higher ROI and lower Operating-Income/TA as well.

The only statistically significant coefficient on a director variable for the entire first set of 1986-90 regressions (Panel I.A.1.) appears in the first column: ex-bankers are negatively associated with high Tobin's Q. In Panel I.A.2., we substitute for the actual number of outside directors of each type their fractional representation on the board. The results mirror those of Panel I.A.1.

When we substitute a dummy variable for whether a firm has any director of a given type, the significance of the banker coefficient disappears. Instead, bankers now are associated with both lower accounting earnings and higher Growth rates (Pan. I.A.3.). When we substitute for these director-type variables (i) a general variable for the total number of outside directors (Pan. I.A.4.), or (ii) a dummy for the presence of a majority of outide directors, the results are uniformly insignificant (Pan. I.A.5.).

4. OLS, 1990-94, total board composition. -- Our regressions on early 1990s data tell much the same story (Pan. II.A.): again, 1990 board composition has little observable effect on 1990-94 performance. The number of Past Bankers is no longer associated with any significant resuts, but two other results now haphazardly appear: (a) Past Bureaucrats are associated with lower 
shareholder ROI, and (b) Concurrent (but not Past) Bankers are associated with higher Ordinary-Inc/Eq. ${ }^{25}$ In regressions using fractional board composition and dummy variables, Concurrent Bankers remain associated with higher Ordinary-Income/Eq, but the observable effect of Past Bureaucrats disappears. In regressions using dummy variables indicating the presence of any directors of a given type, Concurrent Bankers are still associated with higher Ordinary-Income/Eq, but directors from other firms are now associated with lower OperatingIncome/TA.

As with the earlier period, the regressions using either the Total Outside Directors or a Majority Outside Directors dummy are uniformly insignificant.

5. Changes. -- Several readers urged us to explore whether changes in the number of outside directors were associated with changes in performance. Given the poor fit of the director variables in Table 10, one would not expect changes in such variables to be associated with performance changes -- and so we find. Instead, in these regressions (available upon request; we do not have change in ROI data), most calculated coefficients are insignificant, and those that are significant are haphazard.

Thus, increases in Past Bankers are associated with higher $\mathbf{Q}$ and lower OrdinaryIncome/Eq, but only for 1986-90. Increases in Concurrent Bankers are also associated with lower Ordinary-Income/Eq, but increases in current business executives from other firms (Concurrent Other Firm) are associated with higher Ordinary-Income/Eq, and retired business executives from other firms (Past Other Firm) are associated with higher Growth. All other coefficients on the specific director variables are insignificant. Increases in Total Outside Directors are associated with higher Growth rates for both periods, but otherwise yield only insignificant results.

6. Executive directors. -- Regressions on the composition of the executive board appear different, but only superficially so. Initially, they suggest that Concurrent Bankers are strongly associated with higher stock-market (and accounting data) performance: the coefficients on Concurrent Banker are consistently and extremely high in all regressions on Tobin's $\mathbf{Q}$. In fact, however, the regressions mislead. Because we have $\mathbf{Q}$ data only on the manufacturing firms, these regressions involve 300+ firms. In 1986-90, only one of these firms had a current banker on its executive board. In 1990-94, only two had such an executive director, of the two only one had a positive Tobin's Q. In 1986-90, all coefficients on executive directors other than Concurrent Bankers are insignificant. In 1990-94, Past Bureaucrats are associated with lower shareholder ROI and current executives from other firms (Concurrent Other Firm) are associated with lower Operating-Income/TA.

7. Instrumental variables. -- When observers argue that Japanese firms maintain a suboptimal number of outside directors, in effect they argue that Japanese firms do not pick their directors with an eye on expected performance. In effect, they argue that board composition is not endogenous to performance. Accordingly, to test their claims we rely on the OLS regressions in Table 10. Most scholars who test the analogous claims in the U.S. similarly use OLS, and -- in the article that spawned this literature -- so do Demsetz and Lehn.

${ }^{25}$ Though note in Table 9 that the average Q, ROI, and Operating-Income/TA are lower than the average firm for those with Concurrrent Bankers in 1990-94, and that the average ROI and Growth are lower for Concurrent Banker firms in 1986-90. 
Nonetheless, several readers argued that even firms with suboptimal levels of outside directors might choose their boards in part to augment expected performance. Although we lack suitable instruments to use two-stage procedures on most of our sample, Table 7 suggests that we may yet be able to use revenue data to instrument our construction firm directors. Accordingly, we treat Past Bureaucrat and Past Other Firm as endogenous, and instrument them through Construction Rev and Civil Eng Rev (Tab. 11, Pan. A). These revenue measures are not themselves associated with higher or lower profitability, and as instruments have acceptable levels of power. According to Stock \& Watson (2003, p. 350), we "do not need to worrry about weak instruments if the first-stage F-statistic exceeds 10." Here, the first-stage F-statistic is comfortably beyond 10. In the regressions on Past Bureaucrat it is 16.23, and in those on Past Other Firm is 13.40 .

Because Past Bureaucrat and Past Other Firm involve count data, we would prefer to use Poisson to OLS. Unfortunately, using Poisson estimates for the first stage of an instrumental variables framework creates its own econometric problems. As a proxy for the Poisson predicted values, we thus use OLS. In fact, however, OLS and Poisson regressions of board composition on the two revenue variables generate much the same predicted values. Solely to demonstrate that similarity, we include Panel B: Poisson and OLS estimates of our endogenous variables. For Past Other Firm, the correlation coefficient between the OLS and Poisson predicted values is 0.99; for Past Bureaucrat, it is 0.98 .

We report our 2SLS results in Table 11 Panel A. Consistently, they confirm the endogeneity that economic theory predicts: regressing performance on board composition yields no observable significant results. None of the coefficients on either Past Bureaucrat or Past Other Firm is statistically significant.

[Insert Table 11 about here.]

8. Conclusion. -- Consistent with the logic of market competition, outside directors in our database are not observably associated with higher performance. From this, we conclude that firms may be appointing outsiders at levels close to their firm-specific optimum.

When we announced our conclusion in earlier drafts, however, several readers urged us to put a "spin" on those "significant" coefficients that we did obtain. That strikes us as the wrong approach. According to Table 10, in one regression or another retired bankers are "significantly" associated with lower Q, Operating-Income/TA, and Ordinary-Income/Eq, but with higher Growth; bankers who have not yet quit their banking posts are associated with higher $\mathbf{Q}$, Operating-Income/TA, and Ordinary-Income/Eq. Directors from other firms are associated with lower Ordinary-Income/TA, and retired bureaucrats are associated not just with higher Ordinary-Income/Eq, but with both higher and lower ROI.

These effects strike us simply as haphazard. Of the 340 calculated coefficients on director variables, we have results that are "statistically significant" at the 5 percent level in 23 -- or 7 percent. Exclude the five misleading coefficients involving Concurrent Banker executive directors and Q, and we have coefficients significant at the 5 percent level for 5 percent of our cases. Rather than explain the "significant" coefficients as a function of what these directors accomplish, we suggest that readers instead assign the "significance" to random variation.

IV. Summary

As in the U.S., so too in Japan: reformers urge firms to appoint more outside directors. Yet as in the U.S., so too in Japan: the logic of market competition should make us wonder. Provided 
boards matter, by standard economic theory market competition should drive firms toward their firm-specifically optimal board structure.

That optimum need not involve many outside directors. After all, some outsiders may trade firm-specific expertise for their independence. If expertise specific to the firm matters, then the optimal fraction of outside directors will not equal 1 . Instead, it will vary from industry to industry, firm to firm. Where knowledge specific to the firm matters more than independence, firms will appoint more inside directors. Where independence matters more than such firm-specific expertise, they will appoint more outsiders.

All this suggests testable alternatives. If the reformists are right, then Japanese firms have inefficiently few outsiders. Provided at least some substantial minority of the firms have outsiders, then those firms with more outsiders should observably outperform those with fewer. By contrast, if market constraints drive firms toward their firm-specific optimum, then firm characteristics should determine board structure, but that structure should show no observable relation to firm performance.

To test these hypotheses, we assemble board composition and financial data on the largest Japanese firms -- the approximately 1000 firms listed on Section 1 of the Tokyo Stock Exchange in the 1980s and early 1990s. We first explore which firms appoint outsiders. We find that firms most often appoint retired bankers when they borrow heavily, when the firm has fewer mortgageable assets, or when the firm is in the service and finance industry. They appoint retired government bureaucrats when they are in construction, and sell a large fraction of their output to government agencies. And they appoint other retired executives when they have a dominant parent corporation, or when they are in the construction industry selling heavily to the private sector.

Firms with more outside directors do not visibly outperform those with fewer. When we regress firm performance on board composition, we largely obtain insignificant results. The statement holds whether we use OLS or 2SLS and whether we examine the go-go 1980s or the depressed 1990s, and the few significant results are not robust to alternative specifications. Firms with more outside directors simply do not observably outperform those with fewer. Apparently, board composition may indeed be endogenous: market constraints may indeed push firms toward their firm-specifically optimal board structure. 
Table 1: Selected Summary Statistics --

Total and Type of Outside Directors, All Industries and Years

N $\quad$\begin{tabular}{cr} 
Full Board \\
\cline { 3 - 4 }
\end{tabular}

A. Boards and Outsiders, All Firms

1. Total Directors

$\begin{array}{lrllll}\text { Total Directors } & & & \\ 1985 & 1029 & 6 & 18 & 19.49 & 54 \\ 1990 & 1134 & 6 & 19 & 21.16 & 59 \\ 1995 & 1197 & 7 & 19 & 21.26 & 60 \\ \text { Total } & 10 u t s i d e r s & & & & \\ 1985 & 1134 & 0 & 4 & 4.90 & 29 \\ 1990 & 1197 & 0 & 4 & 5.14 & 23 \\ 1995 & & & & & \end{array}$

B. Boards and Outsiders, Firms with 21 or more Directors

1. Total Directors

C. Boards and Outsiders, by Industry (1985)

1. Total Directors

\begin{tabular}{|c|c|c|c|c|c|c|c|c|c|c|}
\hline & 1985 & 366 & 21 & 25 & 26.99 & 54 & 2 & 11 & 11.68 & 32 \\
\hline & 1990 & 485 & 21 & 26 & 28.14 & 59 & 4 & 11 & 12.17 & 34 \\
\hline & 1995 & 516 & 21 & 26 & 27.99 & 60 & 4 & 10 & 11.61 & 34 \\
\hline 2 . & Total Outsiders & & & & & & & & & \\
\hline & 1985 & 366 & 0 & 5 & 5.38 & 24 & 0 & 2 & 2.34 & 9 \\
\hline & 1990 & 485 & 0 & 4 & 5.31 & 29 & 0 & 2 & 2.50 & 11 \\
\hline & 1995 & 516 & 0 & 5 & 5.78 & 23 & 0 & 1.5 & 2.33 & 10 \\
\hline
\end{tabular}

\begin{tabular}{|c|c|c|c|c|c|c|c|c|c|c|c|c|}
\hline & Construction & 101 & 11 & 23 & 24.98 & 51 & & 2 & 10 & 11.45 & 32 & \\
\hline & Trade & 117 & 7 & 17 & 19.68 & 54 & & 2 & 6 & 7.84 & 28 & \\
\hline & Serv. \& finan. & 43 & 9 & 19 & 19.07 & 32 & & 2 & 6 & 6.54 & 13 & \\
\hline & Transportation & 87 & 7 & 20 & 20.52 & 39 & & 1 & 8 & 8.48 & 20 & \\
\hline & Light Indus. & 131 & 9 & 17 & 17.85 & 40 & & 2 & 6 & 6.92 & 19 & \\
\hline & Chemical & 156 & 8 & 18 & 19.13 & 41 & & 1 & 7 & 7.73 & 23 & \\
\hline & Metals & 119 & 6 & 17 & 18.79 & 52 & & 2 & 7 & 8.14 & 29 & \\
\hline & Machinery & 275 & 8 & 17 & 18.44 & 54 & & 1 & 6 & 7.13 & 20 & \\
\hline \multirow[t]{10}{*}{2.} & Total Outsiders & & & & & & & & & & & \\
\hline & Construction & 101 & 0 & 7 & 8.21 & 19 & & 0 & 4 & 4.46 & 9 & \\
\hline & Trade & 117 & 0 & 3 & 4.14 & 19 & & 0 & 1 & 1.82 & 8 & \\
\hline & Serv. \& finan. & 43 & 0 & 8 & 8.63 & 21 & & 0 & 2 & 2.91 & 6 & \\
\hline & Transportation & 87 & 0 & 4 & 4.82 & 24 & & 0 & 1 & 1.62 & 7 & \\
\hline & Light Indus. & 131 & 0 & 3 & 2.84 & 12 & & 0 & 1 & 1.06 & 6 & \\
\hline & Chemical & 156 & 0 & 3 & 3.75 & 15 & & 0 & 1 & 1.44 & 7 & \\
\hline & Metals & 119 & 0 & 3 & 4.14 & 14 & & 0 & 1 & 1.72 & 8 & \\
\hline & Machinery & 275 & 0 & 4 & 4.65 & 17 & & 0 & 1 & 1.86 & 8 & \\
\hline & & $\mathrm{N}$ & $\underline{0}$ & $1-2$ & $3-4$ & $\begin{array}{l}5 \text { or } \\
\text { more }\end{array}$ & $\begin{array}{l}\mathrm{Maj} \cdot \\
\mathrm{OD} .\end{array}$ & 0 & $1-2$ & $3-4$ & $\begin{array}{l}5 \text { or } \\
\text { more }\end{array}$ & $\begin{array}{l}\mathrm{Maj} . \\
\mathrm{OD} .\end{array}$ \\
\hline \multicolumn{2}{|c|}{ Percentage of Firms } & with & Total & Outsiders & Equal & to -- & & & & & & \\
\hline \multirow[t]{4}{*}{1.} & By Year & & & & & & & & & & & \\
\hline & 1985 & 1029 & 10.11 & 22.74 & 23.23 & 43.93 & 15.16 & 28.47 & 39.55 & 20.02 & 11.95 & 23.13 \\
\hline & 1990 & 1134 & 9.08 & 21.50 & 22.22 & 47.09 & 11.73 & 26.92 & 37.78 & 20.65 & 14.65 & 22.22 \\
\hline & 1995 & 1197 & 6.10 & 22.56 & 22.81 & 48.54 & 12.61 & 27.82 & 40.70 & 20.47 & 11.45 & 21.05 \\
\hline \multirow[t]{9}{*}{2.} & By Industry (19 & 85) & & & & & & & & & & \\
\hline & Construction & 101 & 1.98 & 1.98 & 8.91 & 87.13 & 26.73 & 3.96 & 14.85 & 32.67 & 48.51 & 37.62 \\
\hline & Trade & 117 & 11.11 & 30.77 & 19.66 & 38.46 & 10.26 & 29.91 & 42.74 & 17.95 & 9.40 & 23.08 \\
\hline & Serv. \& finan. & 43 & 2.33 & 11.63 & 13.96 & 72.09 & 51.16 & 13.95 & 41.86 & 13.95 & 30.23 & 48.84 \\
\hline & Transportation & 87 & 10.34 & 17.24 & 25.29 & 47.13 & 13.79 & 31.03 & 44.83 & 13.79 & 10.34 & 22.99 \\
\hline & Light Indus. & 131 & 19.85 & 26.72 & 33.59 & 19.85 & 6.11 & 41.98 & 45.80 & 10.69 & 1.53 & 12.21 \\
\hline & Chemical & 156 & 14.74 & 28.21 & 21.79 & 35.26 & 8.97 & 33.97 & 43.59 & 20.51 & 1.92 & 12.82 \\
\hline & Metals & 119 & 10.08 & 26.05 & 26.05 & 37.82 & 12.61 & 29.41 & 42.86 & 19.33 & 8.40 & 21.85 \\
\hline & Machinery & 275 & 6.55 & 24.00 & 25.45 & 44.00 & 16.73 & 28.36 & 38.55 & 23.63 & 9.45 & 25.45 \\
\hline
\end{tabular}

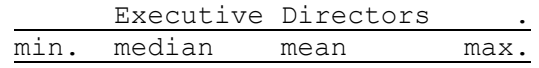

\begin{tabular}{cccc} 
& Executive & Directors & . \\
\hline min. & median & mean & max. \\
& & & \\
1 & 7 & 7.91 & 32 \\
1 & 8 & 8.66 & 34 \\
1 & 7 & 8.23 & 34 \\
0 & 1 & 1.95 & 9 \\
0 & 2 & 2.15 & 11 \\
0 & 1 & 1.96 & 10
\end{tabular}

Note: The first column gives the number of firms; the next 4 columns give the percentage of firms with 0 outsiders, 1 or 2 outsiders, 3 or 4 outsiders, or 5 or more outsiders; the sixth column gives the percentage of firms with a majority of outside directors; and the remaining columns give the comparable percentages if one looks only at the executive directors. 
Outside Directors in Japan: Page 23

Table 1: Selected Summary Statistics (Continued)

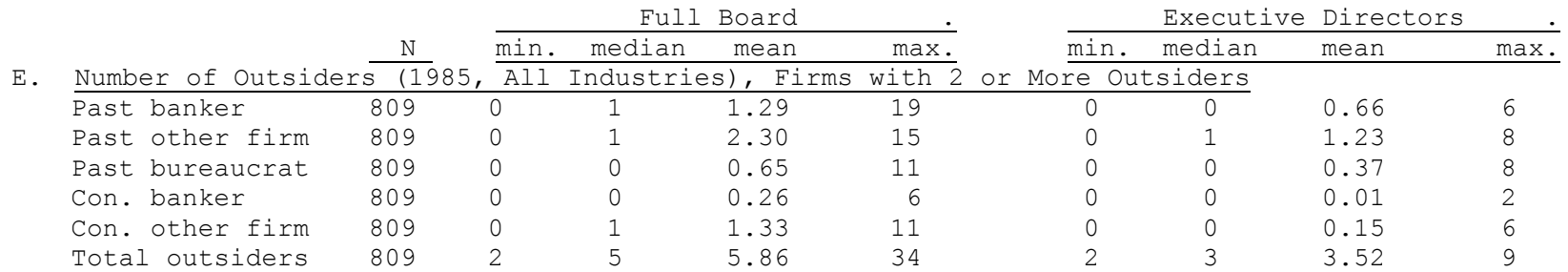

Note: For the comparable statistics on the number of outsiders (by outsider category) at all firms, see Table 2, Panel A.

\begin{tabular}{|c|c|c|c|c|c|c|}
\hline & 1985 & 1990 & 1995 & 1985 & 1990 & 1995 \\
\hline Mean Percentage & Outsiders, by Outsider & Category & & & & \\
\hline Past banker & 5.87 & 5.27 & 5.50 & 7.38 & 6.86 & 6.16 \\
\hline Past other firm & 10.49 & 11.12 & 11.85 & 14.74 & 15.62 & 15.75 \\
\hline Past bureaucrat & 2.41 & 2.13 & 2.16 & 2.48 & 2.64 & 2.56 \\
\hline Con. banker & 1.06 & 0.96 & 0.91 & 0.25 & 0.19 & 0.08 \\
\hline Con. other firm & 5.87 & 5.39 & 5.35 & 1.89 & 1.91 & 1.41 \\
\hline Total outsiders & 25.60 & 24.86 & 25.78 & 27.22 & 27.23 & 25.95 \\
\hline
\end{tabular}

G. Change Over Time in Number of Outside Directors

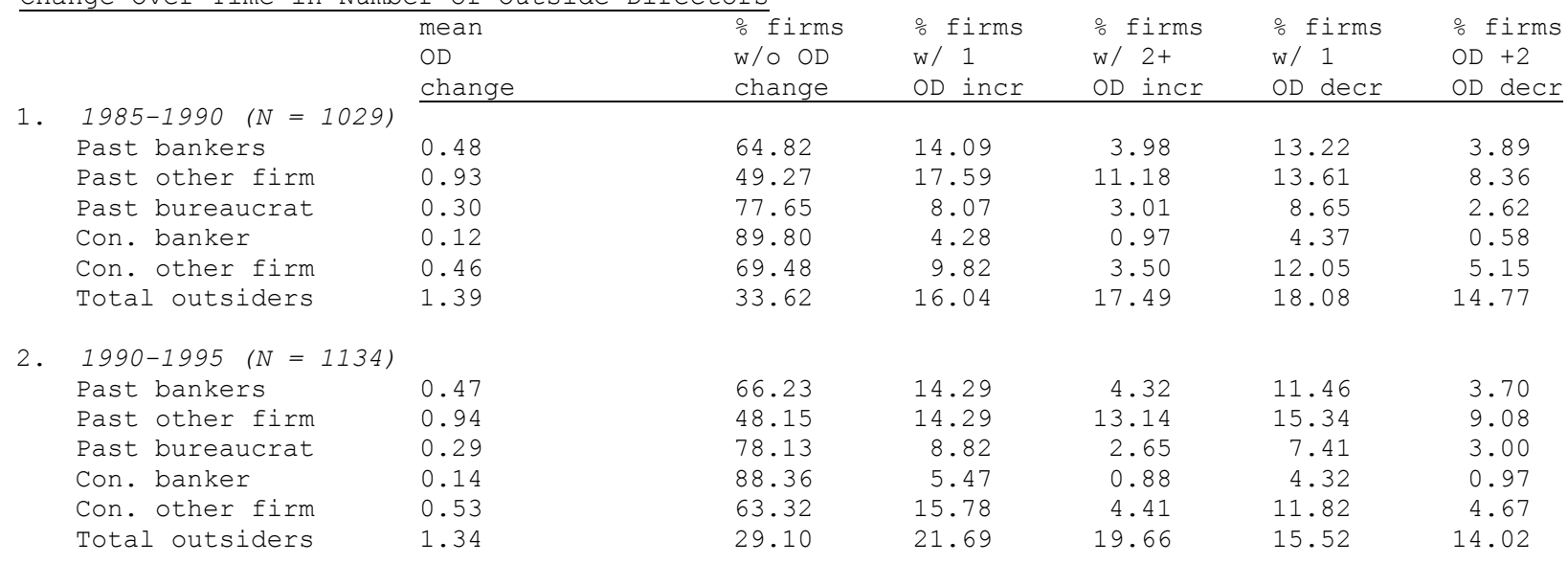

Note: The first column gives the mean change in the absolute value of the number of outside directors at the firm; the remaining columns give the percentage of firms registering no change in the number of outside directors of a given category, registering an increase or decrease of 1 outside director, or registering an increase or decrease of 2 or more.

Sources: Nikkei QUICK joho, K.K., NEEDS (Tokyo, Nikkei QUICK joho, as updated); Nikkei QUICK joho, K.K., QUICK (Tokyo, Nikkei QUICK joho, as updated); Nihon shoken keizai kenkyu jo, ed., Kabushiki toshi shueki ritsu [Rates of Return on Common Stocks] (Tokyo: Nihon shoken keizai kenkyu jo, updated); Toyo keizai, ed., Kigyo keiretsu soran [Firm Keiretsu Overview] (Tokyo: Toyo keizai, as updated); Kazumi Asako, et al., Setsubi toshi to tochi toshi: 1977-1994 [Investment in Equipment and Investment in Land: 1977-1994, in Kazumi Asako \& Masayuki Otaki, ed., Gendai makuro keizai dogaku [Contemporary Macro-economic Dynamics] (Tokyo: University of Tokyo Press, 1997). 
Table 2: Selected Summary Statistics --

Type of Outside Directors by Industry, 1985

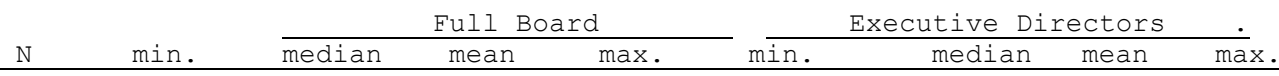

A. All Industries Past bankers

Past bure

Con. banker 1029

Con. other firm 1029

B. Construction

Past bankers $\quad 101$

Past other firm 101

Past bureaucrat 101

Con. banker

Con. other firm 101

C. Trade

Past bankers $\quad 117$

Past other firm 117

Past bureaucrat 117

Con. banker 117

Con. other firm 117

D. Service \& finance

Past bankers

Past other firm

Past bureaucrat

Con. banker

Con. other firm

\section{3}

43

43

43

Transportation

Past bankers

Past other firm

Past bureaucrat

Con. banker

Con. other firm

F. Light Industry

Past bankers

Past other firm 131

Past bureaucrat 131

Con. banker 131

Con. other firm 131

G. Chemical

Past bankers

Past other firm

Past bureaucrat

Con. banker

H. Metals

Past bankers 119

Past other firm 119

Past bureaucrat 119

Con. banker 119

Con. other firm 119

I. Machinery

Past bankers 275

Past other firm 275

Past bureaucrat 275

Con banker 275

Con. other firm 275

Sources: See Table 1.

\section{$1.06 \quad 19$}

1.83

0.53

0.22

1.06

11

6

$$
11
$$

$\begin{array}{rr}1.18 & 6 \\ 3.50 & 13 \\ 2.57 & 11 \\ 0.07 & 1 \\ 0.89 & 8\end{array}$

0.91

1.90

0.26

0.12

0.95

$2.42 \quad 19$

$2.51 \quad 12$

0.67

0.60

2.42

1.01

1.24

0.53

0.49

1.54

0.97

0.85

0.18

0.15

0.69

1.08

1.24

0.13

0.28

1.02

0.80

1.71

0.36

0.14

1.13

1.03

2.13

0.32

0.19

0.98
0.54

0.98

0.30

0.01

0.12

0.69

1.95

1.71

0.01

0.09

0.50

0.97

0.09

0.12

0.21

1.12

1.09

0.28

0.05

0.37

0.51

0.66

0.30

0.01

0.15

0.46

0.41

0.08

0.02

0.08

0.60

0.72

0.08

0.01

0.04

0.39

0.98

0.25

0.01

0.08

0.49

1.13

0.13

0.01

0.11 ax. 
Table 3: Selected Summary Statistics --

Firm Characteristics

$\mathrm{n}$

A. Performance Variables:

Q $(1986-90)$

Q (1990-94)

ROI (1985-90)

ROI (1990-95)

Operating-Inc/TA (1986-90)

Operating-Inc/TA (1990-94)

Ordinary-Inc/Eq (1986-90)

Ordinary-Inc/Eq (1990-94)

Growth (1990-94)
Growth (1986-90)
320

324

941

1,054

1,190

1,197

1,190

1,197

1,142

1,190
Min

$$
\begin{array}{r}
-30.731 \\
-36.238 \\
-15.3 \\
-45 \\
-.336 \\
-.133 \\
-.318 \\
-4.346 \\
-59.010 \\
-72.898
\end{array}
$$

1,029

1,134

1,197

Dominant $\mathrm{S} / \mathrm{h}$ (1995)
1,190

1,190

1,190

1,190

1,190
1,197

1,197

1,197

1,197

1,197
Mean

$\operatorname{Max}$
31.043

23.248

78.6

14.7

.446

.370

3. 700

.841

$1,197.568$

506.911

Sales/TA

Bank Debt/TA

3,182

.001

.058

0

.007

.0003

.047

0

66.840

20.490

.204

.185

.194

4.325

244,203

.244

1.125

.202

198.31

$10,900,000$

.916

7.435

.887

Sources: See Table 1 .

$\begin{array}{rr}4.325 & 262.064 \\ 323.422 & 11,700,000 \\ .258 & .919 \\ 1.011 & 9.047 \\ .176 & .933\end{array}$

00,000

9.047 
I. Regressions of 1985 Board Composition on 1986-90 Financials:

A. All Directors: Dependent Variable

\begin{tabular}{|c|c|c|c|c|c|c|c|c|c|c|}
\hline & & & Past $\mathrm{H}$ & ositio & & & & Con. & ssition & \\
\hline & (1) $\mathrm{Bar}$ & & (2) Bur & $e a u^{\prime} t$ & (3) Oth & Firm & (4) $\mathrm{Ban}$ & $\mathrm{k}$ & (5) Oth & er Firm \\
\hline Total Dirs & .017 & $(2.03)$ & .045 & $(4.69)$ & .008 & $(0.90)$ & .048 & $(4.04)$ & .039 & $(4.15)$ \\
\hline Dominant $\mathrm{S} / \mathrm{h}$ & -.884 & $(6.62)$ & -.325 & $(1.71)$ & 1.014( & $10.59)$ & -.572 & $(2.34)$ & 1.1131 & $10.66)$ \\
\hline ROI & -.005 & $(1.35)$ & .006 & $(1.01)$ & -.003 & $(0.87)$ & .006 & $(0.78)$ & -.003 & $(0.81)$ \\
\hline Volatility & -6.746 & $(0.19)$ & 10.988 & $(0.11)$ & 25.508 & $(0.70)$ & 58.672 & $(1.00)$ & 91.758 & $(2.70)$ \\
\hline Total Assets $\left(\times 10^{6}\right)$ & -.133 & $(1.28)$ & -.023 & $(0.33)$ & -.562 & $(3.02)$ & .035 & $(0.37)$ & .318 & $(1.91)$ \\
\hline Tang Ast/TA & -.840 & $(2.29)$ & -.337 & $(0.39)$ & .253 & $(0.66)$ & -.319 & $(0.55)$ & .423 & $(1.01)$ \\
\hline Sales/TA & -.023 & $(0.26)$ & -.002 & $(0.02)$ & .036 & $(0.40)$ & -.373 & $(2.11)$ & -.099 & $(1.05)$ \\
\hline Bank Debt/TA & 1.938 & $(9.38)$ & .173 & $(0.44)$ & -.057 & $(0.22)$ & .385 & $(0.89)$ & .237 & $(0.84)$ \\
\hline Industry dummies & & & & & & & & & & \\
\hline Construction & .298 & $(1.48)$ & 1.610 & $(5.34)$ & .826 & $(4.02)$ & -1.053 & $(2.07)$ & -.268 & $(1.00)$ \\
\hline Trade & .034 & $(0.15)$ & -.372 & $(1.03)$ & .382 & $(1.63)$ & .153 & $(0.30)$ & .222 & $(0.95)$ \\
\hline Serv \& Finan & .878 & $(3.98)$ & .589 & $(1.38)$ & .412 & $(1.68)$ & 1.185 & $(3.04)$ & .686 & $(3.47)$ \\
\hline Transportation & .216 & $(0.92)$ & .468 & $(1.55)$ & -.083 & $(0.38)$ & 1.029 & $(2.70)$ & .337 & $(1.45)$ \\
\hline Light Indus & .171 & $(1.01)$ & -.523 & $(1.58)$ & -.413 & $(2.16)$ & .191 & $(0.44)$ & -.103 & $(0.51)$ \\
\hline Chemical & .372 & $(2.52)$ & -.894 & $(2.76)$ & -.194 & $(1.08)$ & .705 & $(1.95)$ & .003 & $(0.02)$ \\
\hline Machinery & .403 & $(2.80)$ & -.067 & $(0.27)$ & .328 & $(2.32)$ & .270 & $(0.76)$ & -.016 & $(0.10)$ \\
\hline Pseudo $\mathrm{R}^{2}$ & . & & .2 & & .1 & & .1 & & .1 & \\
\hline $\mathrm{N}$ & 9 & & 91 & & 91 & & 91 & & 91 & \\
\hline
\end{tabular}

B. Executive Directors:

\begin{tabular}{|c|c|c|c|c|c|c|c|c|c|c|}
\hline & & & & & & & & & & \\
\hline & (1) $\mathrm{Bar}$ & & (2) BuI & $e a u^{\prime} t$ & (3) Oth & Firm & (4) Bank & & (5) $\mathrm{ot}$ & ver Firm \\
\hline Total Dirs & .050 & $(3.41)$ & .084 & $(5.92)$ & .056 & $(3.69)$ & .005 & $(0.06)$ & .042 & $(1.08)$ \\
\hline Dominant $\mathrm{S} / \mathrm{h}$ & -1.089 & $(5.36)$ & -.242 & $(1.12)$ & 1.116 & $(11.77)$ & -.526 & $(0.61)$ & 1.200 & $(4.11)$ \\
\hline ROI & -.007 & $(1.41)$ & .007 & $(1.13)$ & -.001 & $(0.18)$ & .028 & $(1.24)$ & -.013 & $(1.27)$ \\
\hline Volatility & .389 & $(0.01)$ & 82.008 & $(1.50)$ & 6.840 & $(0.17)$ & 132.211 & (1.39) & -3.078 & $(0.04)$ \\
\hline Total Assets $\left(x 10^{6}\right)$ & -.222 & $(1.62)$ & .048 & $(0.60)$ & .781 & $(3.36)$ & -1.62 & $(1.03)$ & -.791 & $(2.53)$ \\
\hline Tang Ast/TA & -.714 & $(1.66)$ & -.870 & $(1.21)$ & .264 & $(0.67)$ & -.738 & $(0.23)$ & -.979 & $(0.91)$ \\
\hline Sales/TA & -.020 & $(0.21)$ & .104 & $(0.76)$ & .104 & $(1.12)$ & -.621 & $(0.85)$ & -.184 & $(0.79)$ \\
\hline Bank Debt/TA & 2.350 & $10.08)$ & .301 & $(0.67)$ & .351 & $(1.35)$ & 2.977 & $(1.60)$ & .263 & $(0.45)$ \\
\hline Industry dummies & & & & & & & & & & \\
\hline Construction & .525 & $(2.11)$ & 1.519 & $(5.01)$ & .640 & $(2.96)$ & .388 & $(0.24)$ & .133 & $(0.20)$ \\
\hline Trade & .349 & $(1.18)$ & -1.171 & $(2.46)$ & .282 & $(1.16)$ & 1.673 & $(0.97)$ & 1.408 & $(2.43)$ \\
\hline Serv \& Finan & 1.008 & $(4.26)$ & .406 & $(0.93)$ & .178 & $(0.69)$ & 1.404 & $(0.88)$ & 1.536 & $(2.71)$ \\
\hline Transportation & .274 & $(1.00)$ & .516 & $(1.63)$ & -.211 & $(0.87)$ & -.066 & $(0.04)$ & 1.050 & $(1.70)$ \\
\hline Light Indus & .253 & $(1.07)$ & -.792 & $(1.89)$ & -.497 & $(2.21)$ & 1.384 & $(1.09)$ & .477 & $(0.83)$ \\
\hline Chemical & .537 & $(2.55)$ & -.740 & $(1.80)$ & -.130 & $(0.73)$ & .830 & $(0.72)$ & -.533 & $(0.86)$ \\
\hline Machinery & .557 & $(2.66)$ & -.362 & $(1.20)$ & .360 & $(2.34)$ & -.332 & $(0.22)$ & .388 & $(0.71)$ \\
\hline Pseudo $R^{2}$ & .1 & & - & & .1 & & .1 & & & \\
\hline $\mathrm{N}$ & 91 & & & & & & & & & \\
\hline
\end{tabular}

II. Regressions of 1990 Board Composition on 1986-90 Financials:

A. All Directors:

\begin{tabular}{|c|c|c|c|c|c|c|c|c|c|}
\hline & & Past & ositi & & & & Con. & osition & \\
\hline & (1) Bank & (2) $\mathrm{Bu}$ & eau't & (3) Oth & Firm & (4) $\mathrm{Bar}$ & & (5) Othe & F Firm \\
\hline Total Dirs & $.009 \quad(1.38)$ & .041 & $(5.68)$ & .006 & $(0.80)$ & .032 & $(3.26)$ & .028 & $(3.19)$ \\
\hline Dominant $\mathrm{S} / \mathrm{h}$ & $(5.99)$ & -.470 & $(1.88)$ & .944( & $(11.69)$ & -.948 & $(2.87)$ & 1.183( & $(10.96)$ \\
\hline ROI & $(1.36)$ & .011 & $(2.18)$ & -.006 & $(2.02)$ & .007 & $(0.93)$ & -.003 & $(0.67)$ \\
\hline Volatility & 13.191 & 11.621 & $(0.12)$ & 28.531 & $(0.92)$ & 56.022 & $(0.84)$ & 103.259 & $(5.06)$ \\
\hline Total Assets (x106) & $(0.09)$ & .041 & $(0.97)$ & -.999 & $(4.08)$ & .060 & $(0.92)$ & -.482 & $(2.60)$ \\
\hline Tang Ast/TA & $(2.13)$ & .000 & $(0.00)$ & .269 & $(0.72)$ & -.684 & $(1.15)$ & .650 & (1.54) \\
\hline Sales/TA & $-.096(1.19)$ & -.117 & $(0.88)$ & .090 & $(1.18)$ & .305 & $(1.75)$ & .104 & $(1.04)$ \\
\hline Bank Debt/TA & $2.038(10.24)$ & -.070 & $(0.18)$ & .230 & $(0.90)$ & .603 & $(1.48)$ & .370 & $(1.27)$ \\
\hline Industry Dummies & & & & & & & & & \\
\hline Construction & $(2.67)$ & 1.376 & $(4.67)$ & .807 & $(4.36)$ & -.753 & $(1.41)$ & -.098 & $(0.39)$ \\
\hline Trade & $(0.18)$ & -.466 & $(1.38)$ & .117 & $(0.65)$ & .436 & $(0.98)$ & .098 & $(0.36)$ \\
\hline Serv \& Finan & $(3.21)$ & .100 & $(0.22)$ & .754 & $(3.38)$ & 1.171 & $(3.07)$ & .800 & $(4.23)$ \\
\hline Transportation & $(0.47)$ & .490 & $(0.11)$ & -.374 & $(1.77)$ & 1.327 & $(3.89)$ & .545 & $(2.27)$ \\
\hline Light Indus & $(1.11)$ & -1.203 & $(3.42)$ & -.331 & $(1.92)$ & -.051 & $(0.11)$ & -.112 & $(0.50)$ \\
\hline Chemical & $(2.55)$ & -.940 & $(3.09)$ & -.197 & $(1.34)$ & .475 & $(1.38)$ & .180 & $(0.91)$ \\
\hline Machinery & $.338 \quad(2.18)$ & -.247 & $(1.00)$ & .263 & $(2.11)$ & .405 & $(1.19)$ & -.045 & $(0.27)$ \\
\hline Pseudo R2 & 0.11 & & 31 & & 19 & & 11 & & 14 \\
\hline $\mathrm{N}$ & 941 & & 41 & & 41 & & 41 & & 41 \\
\hline
\end{tabular}


Table 4: Who Appoints Outsiders? (Continued)

II. Regressions of 1990 Board Composition on 1986-90 Financials (Continued):

B. Executive Directors:

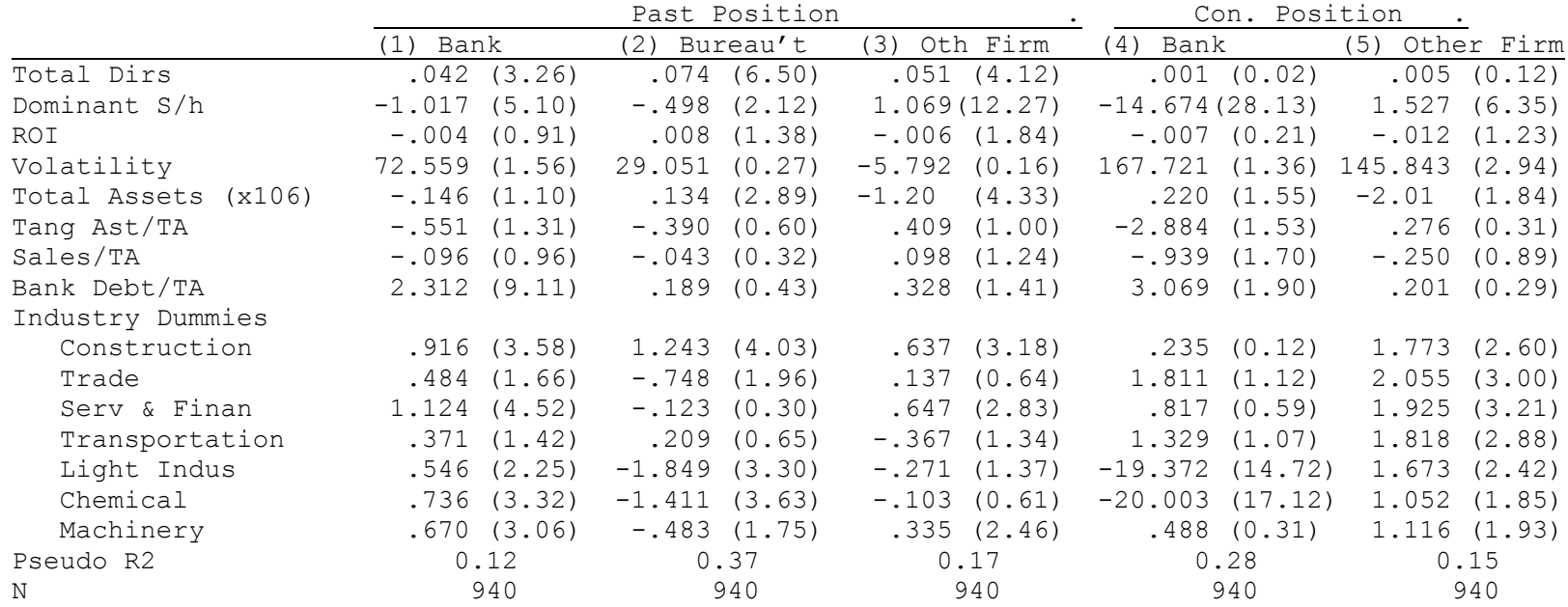

III. Regressions of 1990 Board Composition on 1990-94 Financials:

A. All Directors:

\begin{tabular}{|c|c|c|c|c|c|c|c|c|c|c|}
\hline & & & Past $\mathrm{PC}$ & sition & & & & Con. & sition & \\
\hline & (1) $\mathrm{Ba}$ & & (2) Burf & $a u^{\prime} t$ & Oth & Firm & (4) Bank & & (5) Other & $r$ Firm \\
\hline Total Dirs & .008 & $(1.25)$ & .037 & $(5.13)$ & .013 & $(1.53)$ & .037 & $(3.93)$ & .026 & $(3.14)$ \\
\hline Dominant $\mathrm{S} / \mathrm{h}$ & -.823 & $(5.93)$ & -.644 & $(2.67)$ & 1.044 & $(12.68)$ & -.748 & $(2.44)$ & $1.199(1$ & $12.23)$ \\
\hline $\mathrm{ROI}$ & .001 & $(0.08)$ & -.010 & $(1.09)$ & .007 & $(1.38)$ & .010 & $(0.87)$ & .007 & $(1.04)$ \\
\hline Volatility & .423 & $(0.02)$ & -21.127 & $(0.30)$ & -26.688 & $(0.61)$ & 2.539 & $(0.03)$ & 77.432 & $(2.56)$ \\
\hline Total Assets (x106) & .001 & $(0.08)$ & .060 & $(1.35)$ & -.795 & $(4.09)$ & -.002 & $(0.03)$ & -.303 & $(2.26)$ \\
\hline Tang Ast/TA & -.608 & $(1.64)$ & .171 & $(0.24)$ & -.090 & $(0.29)$ & -.227 & $(0.41)$ & .546 & $(1.49)$ \\
\hline Sales/TA & -.134 & $(1.62)$ & .007 & $(0.05)$ & -.025 & $(0.24)$ & -.401 & $(2.28)$ & .009 & $(0.09)$ \\
\hline Bank Debt/TA & 2.009 & $(7.73)$ & -.051 & $(0.13)$ & .186 & $(0.70)$ & 1.246 & $(2.87)$ & .322( & $(1.10)$ \\
\hline Industry Dummies & & & & & & & & & & \\
\hline Construction & .464 & $(2.47)$ & 1.616 & $(5.74)$ & .556 & $(3.52)$ & -.564 & $(1.14)$ & -.130 & $(0.58)$ \\
\hline Trade & -.057 & $(0.30)$ & -.484 & $(1.55)$ & .095 & $(0.49)$ & .440 & $(1.03)$ & .217 & $(0.94)$ \\
\hline Serv \& Finan & .684 & $(3.45)$ & .127 & $(0.27)$ & .661 & $(3.48)$ & 1.108 & $(2.95)$ & .733 & $(3.88)$ \\
\hline Transportation & -.016 & $(0.07)$ & .617 & $(2.22)$ & -.434 & $(2.32)$ & 1.121 & $(3.28)$ & .571 & $(2.65)$ \\
\hline Light Indus & .140 & $(0.90)$ & 1.061 & $(3.14)$ & -.447 & $(2.73)$ & -.043 & $(0.10)$ & -.191 & $(0.87)$ \\
\hline Chemical & .339 & $(2.22)$ & -.929 & $(3.11)$ & -.287 & $(2.14)$ & .415 & $(1.26)$ & .104 & $(0.55)$ \\
\hline Machinery & .225 & $(1.59)$ & -.195 & $(0.81)$ & .130 & $(1.13)$ & .502 & $(1.54)$ & -.078 & $(0.48)$ \\
\hline Pseudo R2 & & 11 & & 30 & 0.2 & & 0.1 & & 0.13 & \\
\hline $\mathrm{N}$ & & 52 & 105 & & 10 & & 105 & & 1052 & \\
\hline
\end{tabular}

B. Executive Directors:

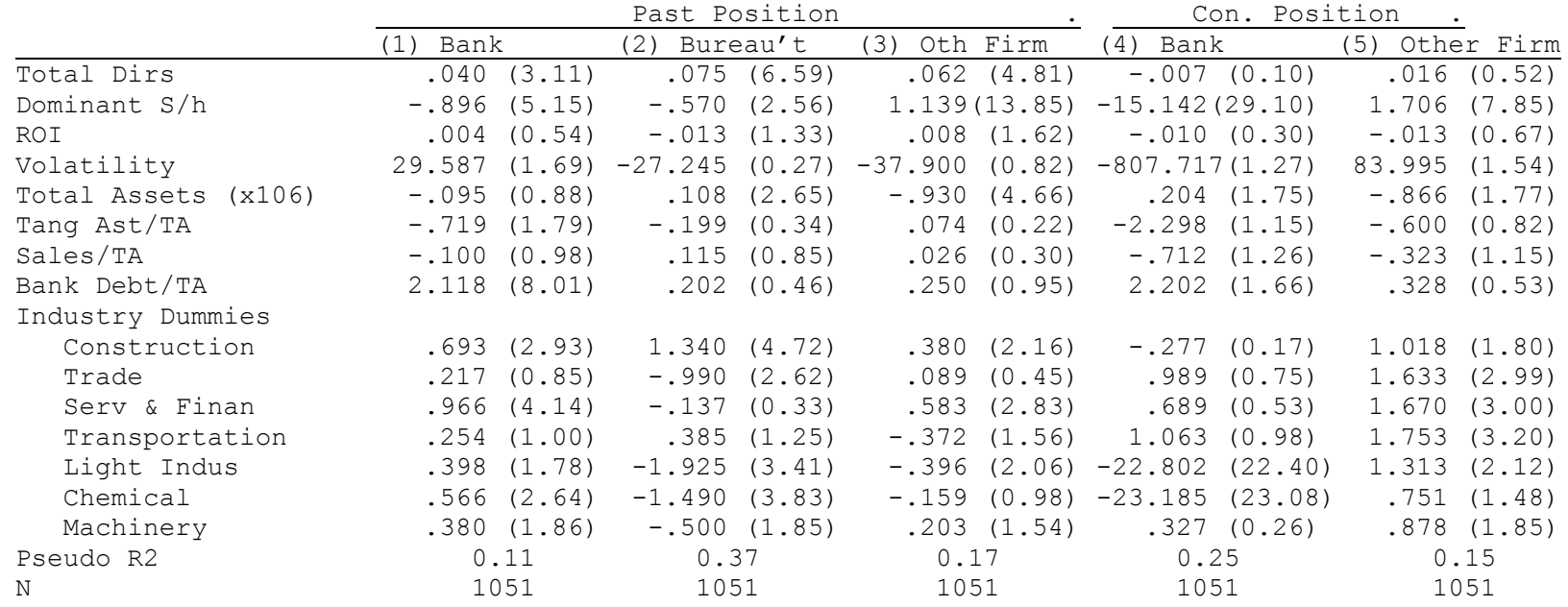


Table 4: Who Appoints Outsiders? (Continued)

IV. Regressions of 1995 Board Composition on 1990-94 Financials:

A. All Directors:

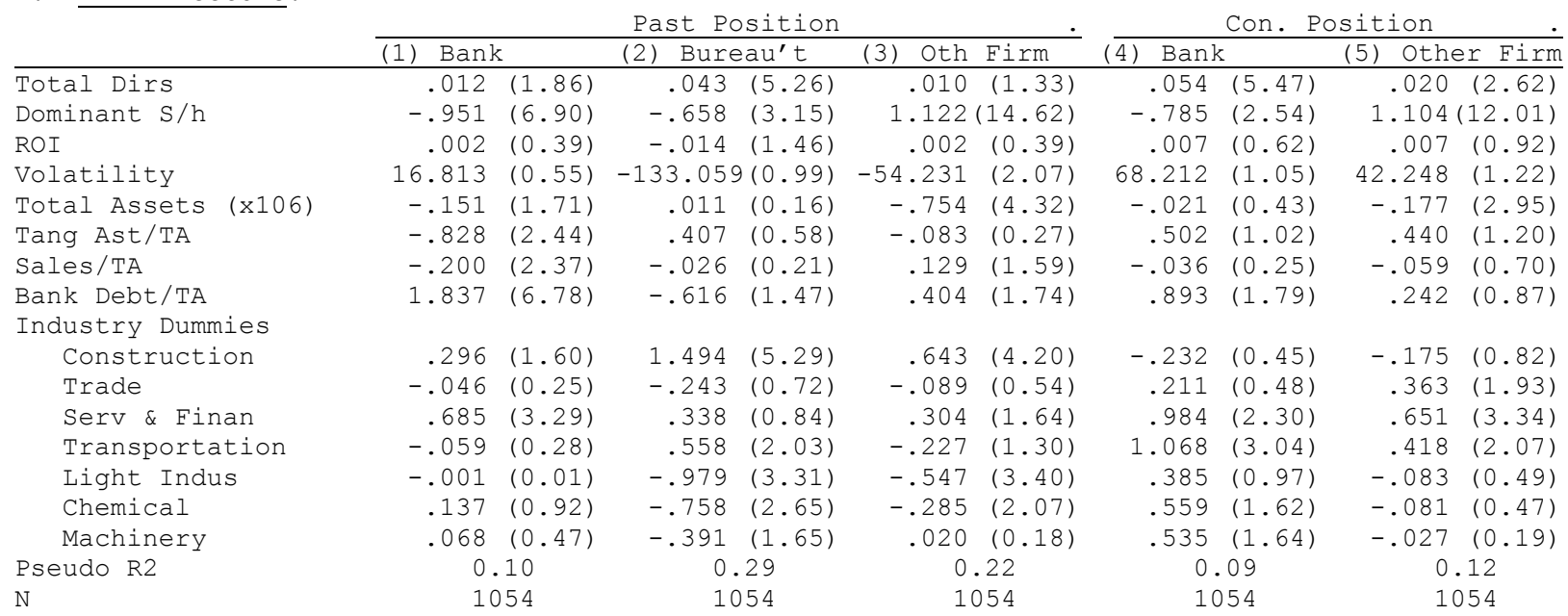

B. Executive Directors:

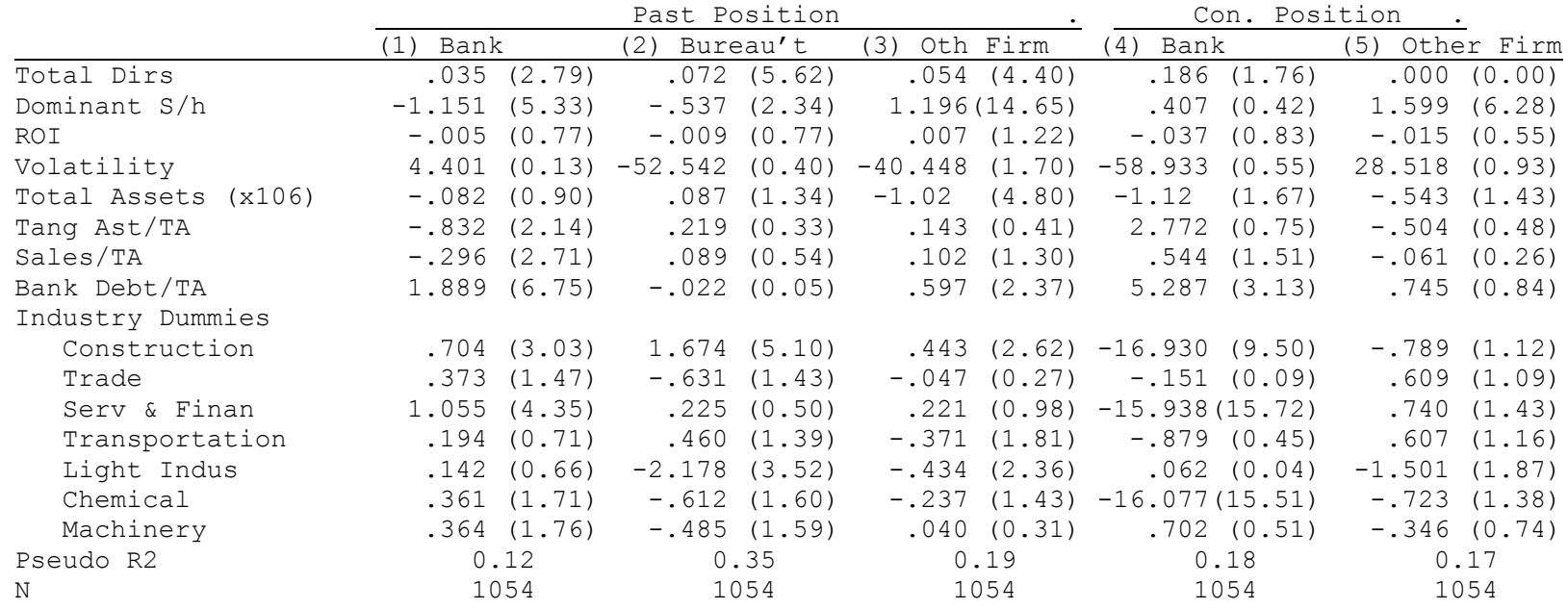

Notes: Poisson estimates on the number of directors on the board (either all directors or executive directors) of a firm who (1) held past positions at a bank, (2) held past positions with the government, (3) held past positions at other non-financial firms, (4) held Con. positions with a bank, or (5) held Con. positions at other non-financial firms.

The table gives the coefficient, followed by the absolute value of the z-statistic, calculated using the Huber-White sandwich estimator of variance. All equations include a constant, not reported here. The omitted industry dummy is Metals. 
Table 5: Who Appoints Outsiders?

Probit Estimates of the Appointment of Any Director

I. Probit Regressions of 1985 Board Composition on 1986-90 Financials (All Directors):

\begin{tabular}{|c|c|c|c|c|c|c|c|c|c|c|c|c|}
\hline & & & $\mathrm{Pas}$ & st $\mathrm{Pc}$ & sition & & & & & Con. & sition & \\
\hline & Bank & & $(2)$ & Bure & $a u^{\prime} t$ & $(3)$ & Oth & Firm & Bank & & (5) Other & r Firm \\
\hline Total Dirs & .023 & $(2.69)$ & & .036 & $(4.07)$ & & .003 & $(0.34)$ & .031 & $(3.56)$ & .016 & $(1.93)$ \\
\hline Dominant $\mathrm{S} / \mathrm{h}$ & -.845 & $(7.24)$ & - & .393 & $(2.92)$ & & .834 & $(6.76)$ & -.230 & $(1.58)$ & 1.140 & $(9.19)$ \\
\hline ROI & .004 & $(1.03)$ & & .001 & $(0.14)$ & & .000 & $(0.11)$ & .005 & $(1.01)$ & -.004 & $(1.02)$ \\
\hline Volatility & -50.993 & $(1.26)$ & & .587 & $(0.18)$ & 29 & .308 & $(0.60)$ & 58.653 & $(1.21)$ & 65.851 & $(1.45)$ \\
\hline Total Assets (x106) & -.333 & $(3.22)$ & & .165 & $(1.50)$ & & .236 & $(2.14)$ & .001 & $(0.02)$ & -.124 & $(1.31)$ \\
\hline Tang Ast/TA & -.444 & $(1.17)$ & & .789 & $(1.75)$ & & .088 & $(0.24)$ & -.059 & $(0.14)$ & .469 & $(1.21)$ \\
\hline Sales/TA & .044 & $(0.47)$ & & .144 & $(1.35)$ & & .051 & $(0.56)$ & -.230 & $(1.99)$ & -.057 & $(0.64)$ \\
\hline Bank Debt/TA & 1.695 & $(6.33)$ & & .258 & $(0.89)$ & & .240 & $(0.95)$ & .266 & $(0.89)$ & .358 & $(1.37)$ \\
\hline Industry Dummies & & & & & & & & & & & & \\
\hline Construction & -.075 & $(0.35)$ & & .025 & $(4.43)$ & & .076 & $(4.50)$ & -.385 & $(1.33)$ & -.218 & $(0.98)$ \\
\hline Trade & -.319 & $(1.49)$ & & .187 & $(0.77)$ & & .259 & $(1.21)$ & .100 & $(0.36)$ & .191 & $(0.87)$ \\
\hline Serv \& Finan & .575 & $(2.24)$ & & .122 & $(0.46)$ & & .385 & $(1.48)$ & .728 & $(2.71)$ & 1.035 & $(3.58)$ \\
\hline Transportation & -.176 & $(0.82)$ & & .395 & $(1.80)$ & & .118 & $(0.57)$ & .601 & $(2.48)$ & $.340 \quad(1$ & $1.57)$ \\
\hline Light Indus & -.103 & $(0.56)$ & & .367 & $(1.78)$ & & .124 & $(0.70)$ & .168 & $(0.73)$ & -.030 & $(0.17)$ \\
\hline Chemical & .176 & $(1.00)$ & & .554 & $(2.77)$ & & .153 & $(0.90)$ & .601 & $(2.87)$ & $.140 \quad(0$. & $.83)$ \\
\hline Machinery & .278 & $(1.73)$ & & .195 & $(1.14)$ & & .275 & $(1.76)$ & .265 & $(1.33)$ & .153 & $(0.96)$ \\
\hline Pseudo R2 & & 10 & & 0.1 & & & & 10 & 0.0 & & 0.1 & \\
\hline $\mathrm{N}$ & & 16 & & 91 & & & & 916 & 91 & & & 16 \\
\hline
\end{tabular}

II. Probit Regressions of 1990 Board Composition on 1990-94 Financials (All Directors) :

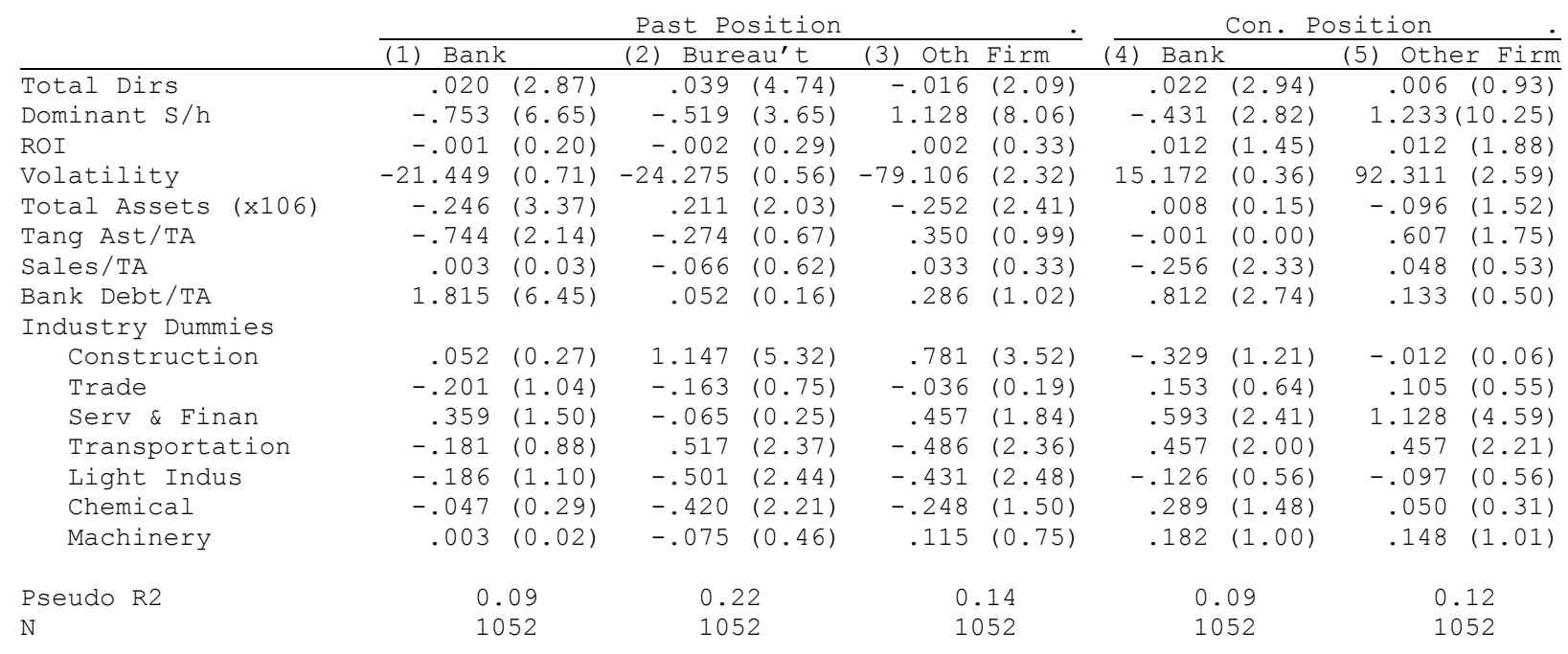

Notes: Probit regressions on the likelihood of the appointment of any director (whether or not an executive director) who (1) held past positions at a bank, (2) held past positions with the government, (3) held past positions at other non-financial firms, (4) held Con. positions with a bank, or (5) held Con. positions at other non-financial firms.

The table gives the coefficient, followed by the absolute value of the z-statistic, calculated using the Huber-White sandwich estimator of variance. All equations include a constant, not reported here. The omitted industry dummy is Metals. 
Table 6: Directors from Other Firms

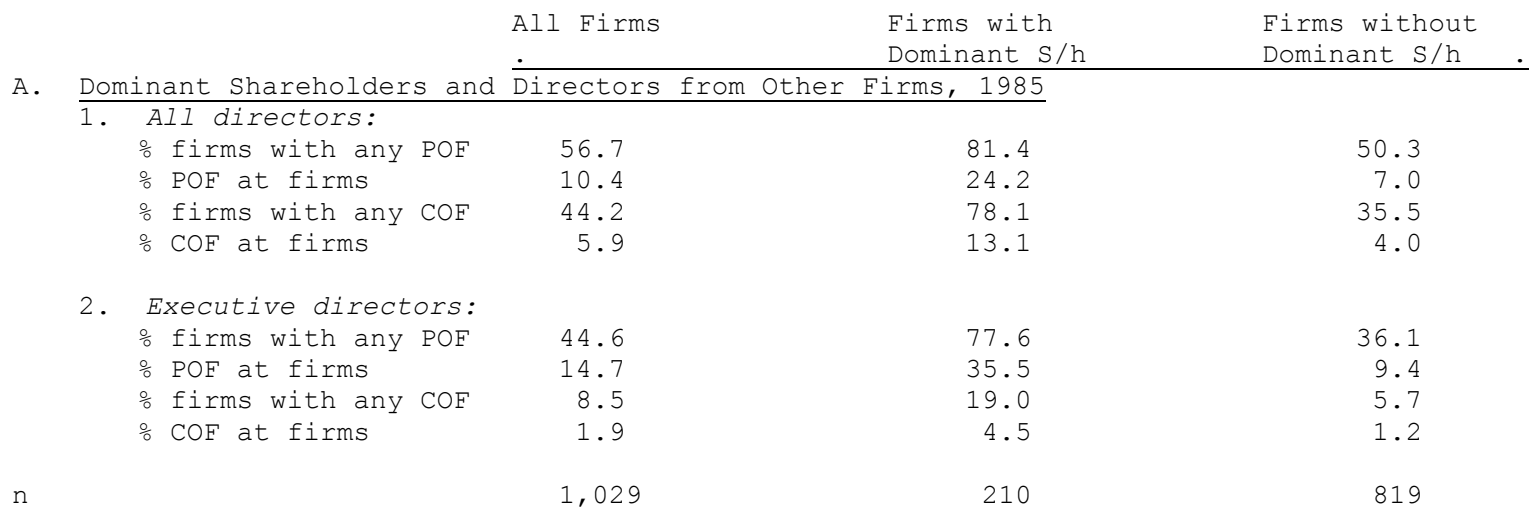

Notes: $\mathrm{POF}==$ past other firm, $\mathrm{COF}=$ concurrent other firm. The table reports the percentage of firms with any POF (line 1 of subpart 1 and 2) or COF (line 3), followed by the mean percentage of such directors at all firms (lines 2 and 4 ).

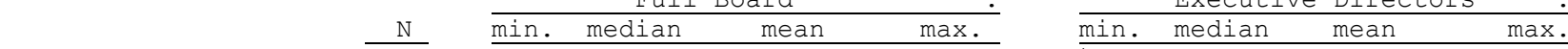

B. Number of Past-other-Firm Directors at Firms without Dominant $\mathrm{s} / \mathrm{h}$

1. Total Directors

$\begin{array}{llllllllll}1985 & 819 & 6 & 18 & 20.01 & 54 & 1 & 7 & 8.23 & 32 \\ 1990 & 924 & 6 & 20 & 21.68 & 59 & 1 & 8 & 8.96 & 34 \\ 1995 & 965 & 7 & 20 & 21.61 & 60 & 1 & 7 & 8.42 & 34\end{array}$

2. Past-other-Firm Directors

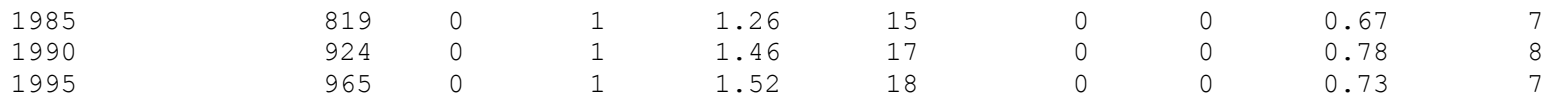

C. Number of Past-Other-Firm Directors at Firms with Dominant $\mathrm{S} / \mathrm{h}$

1. Total Directors

\begin{tabular}{|c|c|c|c|c|c|c|c|c|}
\hline 1985 & 210 & 7 & 17 & 17.48 & 38 & 1 & 6 & 6.63 \\
\hline 1990 & 210 & 9 & 18 & 18.88 & 43 & 2 & 7 & 7.32 \\
\hline 1995 & 232 & 9 & 19 & 19.79 & 44 & 2 & 7 & 7.46 \\
\hline
\end{tabular}

2. Past-Other-Firm Directors

\begin{tabular}{|c|c|c|c|c|c|c|c|c|}
\hline 1985 & 210 & 0 & 4 & 4.04 & 15 & 0 & 2 & 2.20 \\
\hline 1990 & 210 & 0 & 5 & 4.83 & 25 & 0 & 3 & 2.74 \\
\hline & 232 & 0 & 5 & 5.41 & 21 & 0 & 3 & 2.73 \\
\hline
\end{tabular}

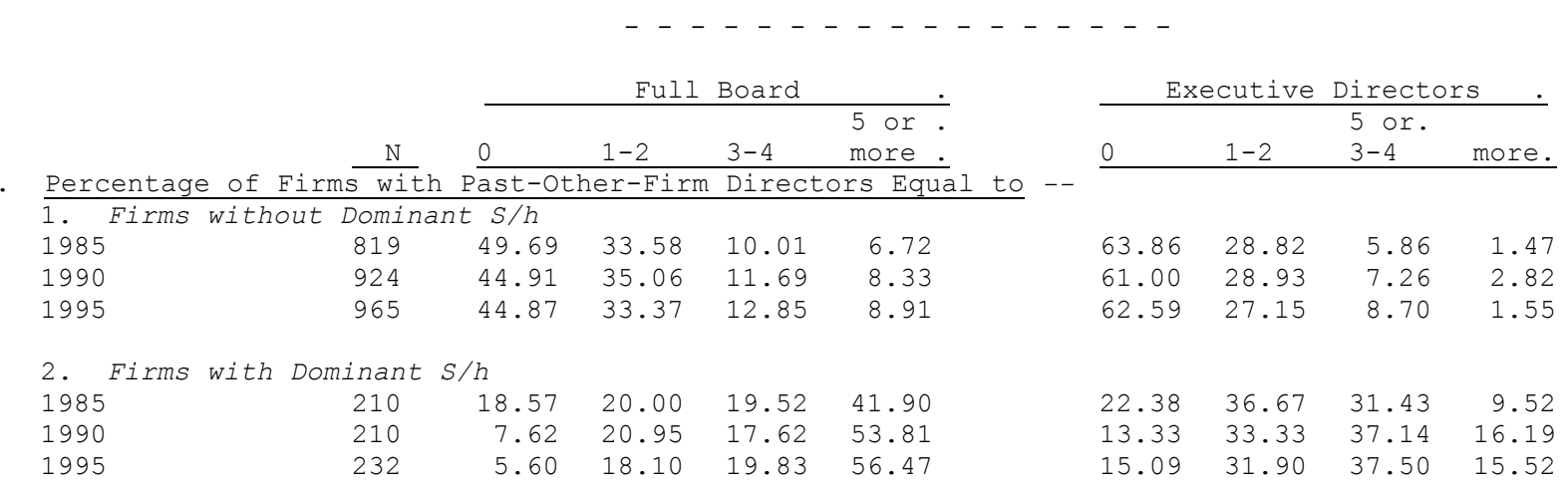


Table 7: Outside Directors in the Construction Industry, Poisson Estimates

Total Directors

Total Executive Dir

Dominant $\mathrm{S} / \mathrm{h}$

Total Assets $\left(x 10^{6}\right)$

Construction Rev

Civil Eng Rev
(A)

(B)

Dependent Variable
(D)

Past Other Firm

\begin{tabular}{|c|c|c|c|c|c|}
\hline All & Dir. & Executive Dir & All & Dir. & Executive Dir. \\
\hline .046 & $(2.89)$ & & -.011 & $(0.73)$ & \\
\hline & & $(6.70)$ & & & $(0.72)$ \\
\hline-.061 & $(0.27)$ & $(1.30)$ & .823 & $(5.30)$ & $(5.46)$ \\
\hline-.556 & $(1.32)$ & $(2.55)$ & 1.914 & $(2.28)$ & $(2.26)$ \\
\hline .008 & $(2.60)$ & $(2.74)$ & .004 & $(1.54)$ & $(1.13)$ \\
\hline .021 & $(5.82)$ & $(4.77)$ & -.006 & $(1.78)$ & $(1.93)$ \\
\hline
\end{tabular}

Pseudo $\mathrm{R}^{2}$

$\mathrm{N}$

$\begin{array}{llll}.25 & .31 & .20 & .15 \\ 101 & 101 & 101 & 101\end{array}$

Notes: The regressions are Poisson. All specifications include a constant term, not reported. The table reports the coefficient, followed by the absolute value of the z-statistic in parenthesis, using the Huber-White sandwich estimator of variance. The dependent variable is the number of directors (or executive directors) with former bureaucratic (or other firm) experience.

Sources: See sources cited in Table 1 and Kaisha shikiho [Seasonal Corporate News ] (Tokyo: Toyo keizai, relevant issues)

\section{Table 8: Public-Sector Construction Expenditures}

\begin{tabular}{|c|c|c|c|c|c|c|c|}
\hline & $\begin{array}{c}\text { National } \\
\text { Government }\end{array}$ & $\begin{array}{c}\text { Public } \\
\text { Organiz'n. }\end{array}$ & $\begin{array}{l}\text { National } \\
\text { Firms }\end{array}$ & $\begin{array}{l}\text { Prefectural } \\
\text { Government }\end{array}$ & $\begin{array}{r}\text { Municipal } \\
\text { Government }\end{array}$ & $\begin{array}{c}\text { Regional } \\
\text { Firms } \\
\end{array}$ & Other \\
\hline 1980 & 1279 & 1013 & $1418(12.4)$ & $(27.8)$ & 3180 & 882 & 484 \\
\hline & $(10.7)$ & 891 & 800 & 35 & 3329 & 848 & 433 \\
\hline 1990 & $(11.5)$ & 1402 & 379 & $(32.1)$ & 4925 & 936 & 605 \\
\hline 1994 & $(11.3)$ & $(8.5)$ & $(2.4)$ & $(32.1)$ & $(34.8)$ & $(6.6)$ & $(4.5)$ \\
\hline
\end{tabular}

Notes: The table gives the amount of construction services purchased, by government unit, in billion yen, followed by the percentage.

Source: Kensetsu sho kensetsu keizai kyoku, ed., Kensetsu tokei yoran [Construction Statistics Overview] (Tokyo: Kensetsu bukka chosa kai, various years). 
Table 9:

Firm Performance and Board Composition -- Summary Statistics

A. 1985 Boards and 1986-90 Performance:

\begin{tabular}{|c|c|c|c|c|c|c|c|c|c|c|}
\hline & \multicolumn{2}{|c|}{1} & \multicolumn{2}{|c|}{$\mathrm{ROI}$} & \multicolumn{2}{|c|}{ OpIn/TA } & \multicolumn{2}{|c|}{ OrIn/Eq } & \multicolumn{2}{|c|}{ Growth } \\
\hline $\begin{array}{ll}\text { 1. } & \text { All firms } \\
\text { 2. } & \text { Firms with }\end{array}$ & 1.834 & (311) & 21.949 & $(916)$ & .048 & $(1029)$ & .133 & $(1029)$ & 55.311 & $(999)$ \\
\hline Majority outsiders & 3.823 & (43) & 22.615 & (131) & .048 & $(156)$ & .117 & $(156)$ & 57.442 & $(152)$ \\
\hline Minority outs & 1.707 & $(23$ & & & .046 & & .134 & & 54 & \\
\hline $\begin{array}{l}\text { No outsiders } \\
\text { 3. Firms with }\end{array}$ & .233 & $(35$ & & & .060 & $(10$ & .148 & & 49.632 & $(102)$ \\
\hline Any past banker & .143 & $(158$ & 22.580 & & .042 & $(549)$ & .116 & & 55.462 & $(525)$ \\
\hline Any past other firm & 2.500 & (155 & 706 & & .047 & $(5$ & .136 & & 44 & 64) \\
\hline Any past bureaucrat & 1.420 & (55) & & & .045 & & .148 & & 39 & 52) \\
\hline Any con. banker & 2.168 & $(50)$ & & & .049 & & .136 & & 1.073 & \\
\hline Any con. other firm & 2.753 & (149) & 21.356 & $(405)$ & .049 & $(455)$ & .142 & $(455)$ & 56.422 & $(444)$ \\
\hline
\end{tabular}

B. 1990 Boards and 1990-94 Performance:

\begin{tabular}{|c|c|c|c|c|c|c|c|c|c|c|}
\hline & \multicolumn{2}{|c|}{ Q } & \multicolumn{2}{|c|}{$\mathrm{ROI}$} & \multicolumn{2}{|c|}{ OpIn/TA } & \multicolumn{2}{|c|}{ OrIn/Eq } & \multicolumn{2}{|c|}{ Growth } \\
\hline $\begin{array}{ll}1 . & \text { All firms } \\
\text { 2. } & \text { Firms with }\end{array}$ & 1.604 & $(324)$ & -10.746 & $(1052)$ & .041 & (1134) & .095 & (1134) & 17.906 & $(1129$ \\
\hline Majority outsiders & .879 & (28) & -11.563 & $(120)$ & .042 & (133) & .054 & & 21.438 & (132) \\
\hline Minority or & 10 & $(25$ & & & 0 & & & & & \\
\hline $\begin{array}{l}\text { No outside } \\
\text { 3. Firms with }\end{array}$ & & & & & .043 & & .088 & & & \\
\hline Any past banker & .311 & $(167)$ & -11.243 & $(56$ & .038 & & .085 & & 18.231 & (597) \\
\hline Any past other firm & 2.057 & $(1$ & & & .040 & & .092 & & & 9) \\
\hline Any past bure & .836 & & & & .0 & & .1 & & & \\
\hline Any con. ban & .155 & & & & 039 & & 108 & & & \\
\hline Any con. other firm & 2.195 & (154) & -10.439 & $(475)$ & 041 & (509) & .086 & $(509)$ & 18.430 & (507) \\
\hline
\end{tabular}

Notes: Per-firm mean values, followed by number of firms in parentheses. For "all firms," we limit the sample to those firms for which we have data on board composition.

Sources: See Table 1 . 
Table 10: What Do Outsiders Do? OLS Estimates, All Industries

General explanation: In each panel, we explore the impact of various director and financial variables on firm performance. In Part I.A. we give the results for 1986-90 using all data on all directors; in Part II.A. we give the results for 1990-94 using all directors; in Part I.B. we give the results for 1986-90 using data on executive directors only; and in Part II.B. we give the results for 1990-94 using data on executive directors only. Within each part, we variously explore the impact of:

(1) the absolute number of directors of each type,

(2) the fractional board composition of directors of each type,

(3) whether the firm had any directors of each type (dummy variables),

(4) the total number of outside directors, and

(5) whether the firm had a majority of outside directors (dummy variables).

As indices of firm performance, we use (a) Tobin's Q, (b) shareholder returns on investment, (c) operating income/total assets, (d) ordinary income/equity, and (e) fractional growth in total assets.

All regressions use OLS. In all cases, we give the coefficient, followed by the absolute value of the robust t-value. All equations include the full range of financial variables given in I.A.1. and II.A.1, but for expositional brevity we elsewhere omit the presentation of their coefficients and t-statistics. All equations also include a constant term, not reported here.

Dependent Variable

(3) Oper Inc/ (4) Ord-Inc/

(2) ROI Tot Asts Equity

(5) Growth

I. 1986-90:

A. All Directors:

1. Number of Directors:

Director Variables

Past bankers

Past other firm

Past bureaucrat

Con. banker

Con. other firm

Board Size

Dominant $\mathrm{S} / \mathrm{h}$

Volatility

Total Assets $\left(\times 10^{5}\right)$

Tang Ast/TA

Bank Debt/TA

Construction

Trade

Serv \& Finan

Transportation

Light Indus

Chemical

Machinery

$\mathrm{R}^{2}$

N

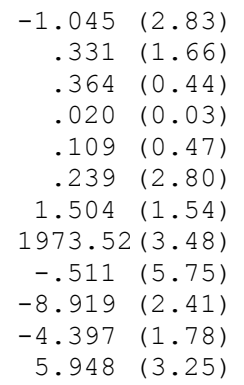

$.948(3.25)$

$3.402 \quad(2.29)$

$3.057 \quad(2.20)$

$2.647 \quad(2.04)$

$$
.20
$$

311
$-.402(1.64)$

$-.101(0.57)$

$.496(1.23)$

$.365(0.65)$

$-.112(0.51)$

-.111 (1.77)

$-.933(0.85)$

$567.00 \quad(0.83)$

$-.153(3.24)$

\begin{tabular}{|c|c|c|c|c|c|}
\hline Past & bankers & -20.464 & $(2.87)$ & -6.461 & $(1.27)$ \\
\hline Past & other firm & 4.184 & $(1.50)$ & -2.400 & $(0.72)$ \\
\hline Past & bureaucrat & 3.746 & $(0.28)$ & 10.697 & $(1.22)$ \\
\hline Con. & banker & 1.319 & $(0.09)$ & 7.571 & $(0.60)$ \\
\hline Con. & other firm & 3.200 & $(0.71)$ & -4.373 & $(0.99)$ \\
\hline & Any Directors & \multicolumn{4}{|c|}{ (dummy variables): } \\
\hline Past & bankers & -1.277 & $(1.66)$ & .761 & $(0.95)$ \\
\hline & other firm & .504 & $(0.69)$ & .039 & $(0.05)$ \\
\hline & bureaucrat & .836 & $(0.83)$ & -.006 & $(0.01)$ \\
\hline & banker & .676 & $(0.61)$ & .890 & $(0.86)$ \\
\hline & other firm & .886 & $(1.18)$ & -.879 & $(1.10)$ \\
\hline
\end{tabular}

$3.036 \quad(1.01)$

$12.531 \quad(5.03)$

$10.925 \quad(5.15)$

$3.519(1.87)$

$.279(0.11)$

$-.272(0.15)$

$-.993(0.62)$

$-5.864(3.85)$

$-3.404 \quad(2.29)$

\section{.18}

916

2. Fractional Board Composition:$$
-.013(1.02)
$$$$
.007 \quad(0.87)
$$$$
.023(1.10)
$$$$
-.005(0.12)
$$$$
-.004(0.26)
$$$$
-.006(3.00)
$$$$
.001(0.54)
$$$$
.002(0.90)
$$$$
.002(0.84)
$$

$.001(0.36)$

$$
\begin{array}{rr}
-.001 & (0.29) \\
.001 & (0.67) \\
-.002 & (0.30) \\
-.007 & (0.36) \\
.006 & (1.85) \\
.002 & (1.75) \\
.010 & (0.72) \\
-3.989 & (0.18) \\
.002 & (3.18) \\
-.026 & (0.80) \\
-.251 & (2.98) \\
.017 & (0.77) \\
-.008 & (0.54) \\
.013 & (0.60) \\
.024 & (1.18) \\
-.028 & (2.11) \\
-.005 & (0.30) \\
-.102 & (3.63)
\end{array}
$$

$$
.18
$$

1029

$$
\begin{aligned}
& -.096(0.99) \\
& .006(0.13)
\end{aligned}
$$

$2.170(1.53)$

$.229(0.34)$

$-1.400(1.05)$

$-2.776(1.21)$

$.889(0.72)$

$-.622(1.88)$

$3.433(0.75)$

$424.789(0.12)$

$.797(1.41)$

$-48.176(2.94)$

$-79.646(7.42)$

$9.222(1.21)$

$7.014(0.90)$

$43.227 \quad(2.73)$

$26.338 \quad(3.53)$

$-1.214(0.18)$

$-754(0.14)$

$-9.162(1.77)$

$-.017(2.32)$

$.005(0.37)$

$.003(0.20)$

$.006 \quad(0.24)$

.017 (1.12)

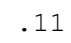

999

$$
\begin{array}{rr}
32.907 & (1.33) \\
5.895 & (0.47) \\
-33.144 & (1.26) \\
-49.944 & (1.14) \\
9.838 & (0.50) \\
& \\
7.167 & (1.94) \\
.244 & (0.06) \\
-3.983 & (0.84) \\
-4.565 & (1.16) \\
3.166 & (0.83)
\end{array}
$$


Outside Directors in Japan: Page 34

Table 10: What Do Outsiders Do? (Continued)

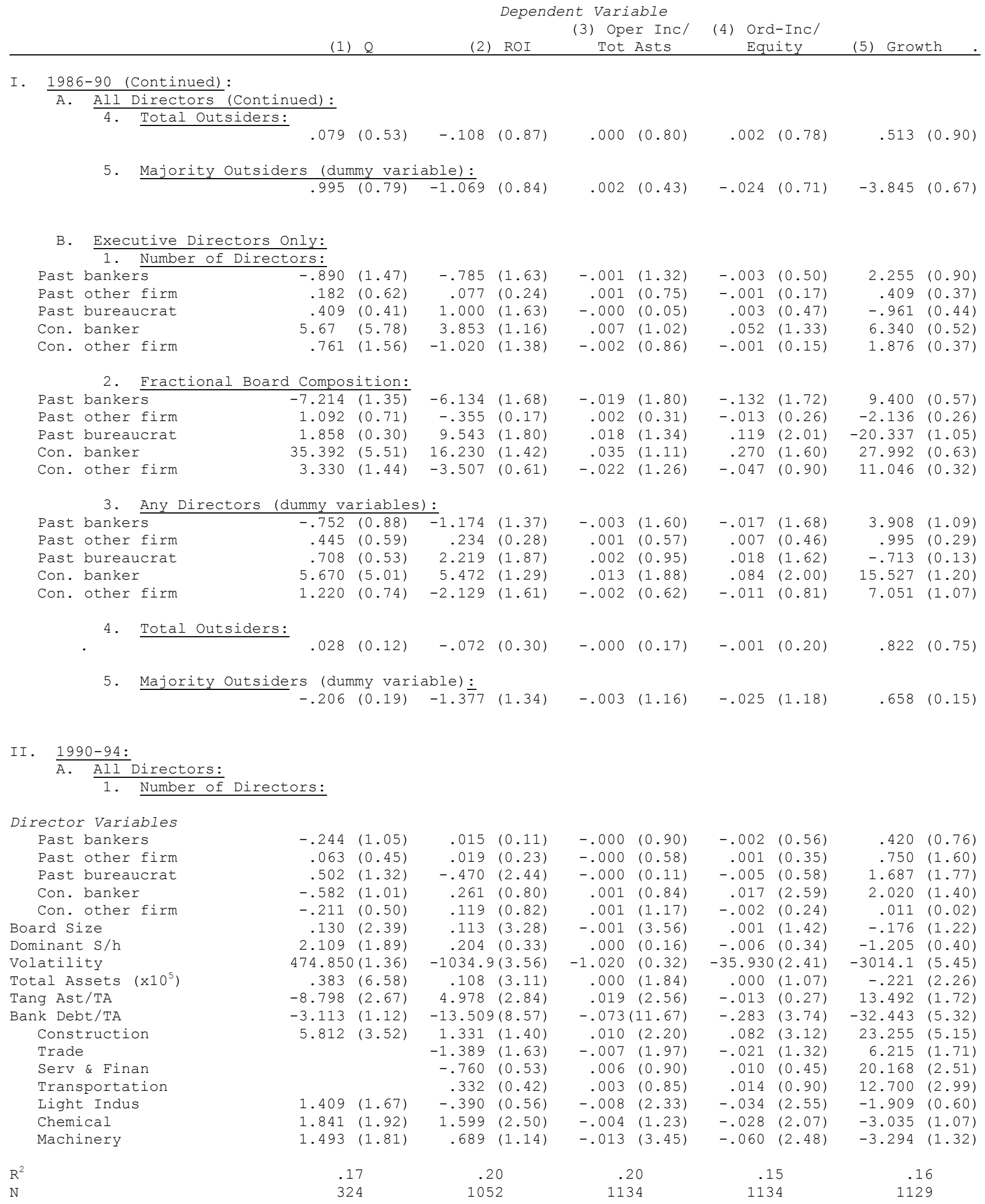


Outside Directors in Japan: Page 35

Table 10: What Do Outsiders Do? (Continued)

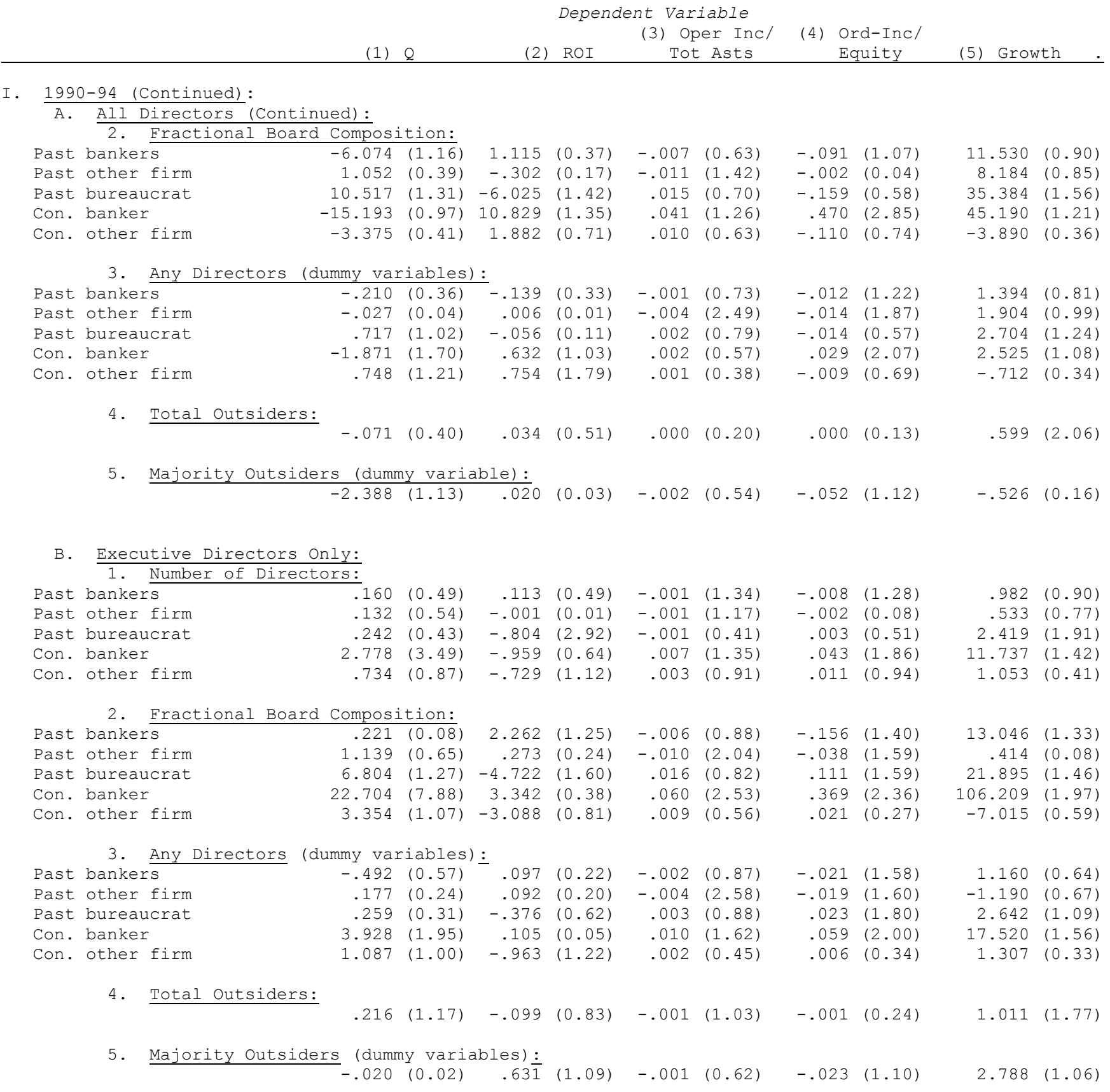


Table 11: What Do Outsiders Do?

The Effect of Board Composition on Performance

in the Construction Industry, 2SLS Estimates for 1986-90

Dependent Variable

(2) Oper Inc/

(3) Ord Inc/

Tot Asts

Equity

(4) Growth.

A. 2SLS

1. Instrumented: Past Bureaucrat

Board Size $\quad .370$ (1.13)

$.370(1.13)$
$-.527(0.18)$

$.003(1.40)$

$-.001(2.43)$

$.013(2.43)$

Dominanat $\mathrm{s} / \mathrm{h}$

$5944.522(1.00)$

$28.190(2.96)$

Total Ast $\left(\times 10^{6}\right)$

$-8.93(1.36)$

$.019(1.53)$

101
$-.003(0.38)$
$.003(1.50)$
$.055(3.01)$
$43.740 \quad(1.33)$
$-.086(1.99)$
101
$-4.650(1.21)$
$-.345(0.29)$
$4.525(0.48)$
$-27481.84(1.64)$
$.000 \quad(0.69)$
96

$\mathrm{N}:$

86

$\begin{array}{cc}\text { Instrumented: } & \text { Past Other Firm } \\ \text { Past Other Firm } & .590 \quad(0.51\end{array}$

Board size .479 (2.03)

Dominant $\mathrm{S} / \mathrm{h} \quad-2.737(0.54)$

Volatility

$2096.429(0.26)$

Total Ast $\left(\times 10^{6}\right)$

$-.000 \quad(1.94)$

86
$.001(0.43)$
$-.001(1.99)$
$.010(1.09)$
$21.804 \quad(1.89)$
$.009(0.93)$
101
$.008 \quad(1.15)$
$.003(2.00)$
$.022(0.67)$
$14.093(0.32)$
$-.076(2.09)$
101

N:

genous Variables

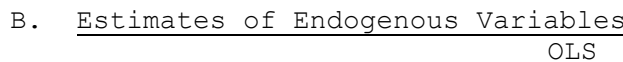

Past Other Firm

Poisson

OLS

Poisson

\begin{tabular}{|c|c|c|c|c|}
\hline & Past Other Firm & Past Other Firm & Past Bureaucrat & Past Bureaucrat \\
\hline Construction Rev & $.012(1.08)$ & $.003(1.13)$ & $.011(2.98)$ & $.011(3.44)$ \\
\hline Civil Eng Rev & $-.024 \quad(1.92)$ & $-.008 \quad(1.96)$ & $.055(7.38)$ & $.025 \quad(7.44)$ \\
\hline $\mathrm{R}^{2}$ or Pseudo $\mathrm{R}^{2}$ & .08 & .05 & .45 & .22 \\
\hline $\mathrm{N}$ & 101 & 101 & 101 & 101 \\
\hline
\end{tabular}

Notes: Construction firms only, using 1985 total directors and 1986-90 financial data. In Panel A, the dependent variable is firm performance during 1986-90, measured by (1) shareholder returns on investment, (2) operating income/total assets, (3) ordinary income/equity, and (4) growth (in total assets, as percentage).

Panel A reports two-stage least squares estimates with Construction Rev and Civil Eng Rev as instruments. Panel B reports OLS and Poisson estimates of the endogenous variables in the Panel A 2SLS estimates.

The tables give the coefficient, followed by the absolute value of the t- or $z$-statistic in parenthesis. In Panel B, the parenthetical gives the robust t-value for the OLS estimates, and for the Poisson estimates the z-statistic calculated using the Huber-White sandwich estimator. All equations include a constant term, not reported here.

Sources: See Table 6 . 


\section{References}

Abe, Y., 1997, "Chief Executive Turnover and Firm Performance in Japan," Journal of Japanese and International Economies, 11, 2.

Agrawal, A. and C.R. Knoeber, 1996, "Firm Performance and Mechanisms to Control Agency Problems between Managers and Shareholders," Journal of Finance and Quantitative Analysis, 31, 377.Agrawal, A. and C.R. Knoeber, 2001, "Do Some Outside Directors Play a Political Role?," Journal of Law and Economics, 44, 179.

Ahmadjian, C.L., 2001, "Changing Japanese Corporate Governance," unpublished.

Aoki, M., 1988, Information, Incentives, and Bargaining in the Japanese Economy, Cambridge, U.K.: Cambridge University Press.

Aoki, M., 2000, Information, Corporate Governance, and Institutional Diversity: Competitiveness in Japan, the USA, and the Transitional Economies, Oxford: Oxford University Press.

Aoki, M., H. Patrick and P. Sheard, 1994, "The Japanese Main Bank System: An Introductory Overview," in M. Aoki and H. Patrick, eds., The Japanese Main Bank System, 1, Oxford: Oxford University Press.

Asako, K., et al., 1997, Setsubi toshi to tochi toshi: 1977-1994 [Investment in Equipment and Investment in Land: 1977-1994], in K. Asako and M. Otaki, eds., Gendai makuro keizai dogaku [Contemporary Macro-economic Dynamics], Tokyo: University of Tokyo Press, 1997.

Bainbridge, S.M., 2002, Corporation Law and Economics, New York: Foundation.

Bathala, C.T. and R.P. Rao, 1995, "The Determinants of Board Composition: An Agency Theory Perspective," Managerial and Decision Economics, 16, 59.

Baysinger, B.D. and H.N. Butler, 1985, "Corporate Governance and the Board of Directors: Performance Effects of Changes in Board Composition," Journal of Law, Economics and Organization, 1, 101.

Beatty, R. and E.J. Zajac, 1994, "Managerial Incentives, Monitoring, and Risk Bearing: A Study of Executive Compensation, Ownership, and Board Structure in Initial Public Offerings," Administrative Science Quarterly, 39, 313.

Bhagat, S. and B. Black, 1999, "The Uncertain Relationship Between Board Composition and Firm Performance," Business Lawyer, 54, 921.

Black, B., 2001, "Does Corporate Governance Matter? A Crude Test Using Russian Data," University of Pennsylvania Law Review, 149: 2131-50.

Black, B., H. Jang and W. Kim, 2003, "Does Corporate Governance Predict Firms' Market Values? Evidence from Korea," Stanford Law School Olin Program Working Paper No. 237.

Blumenthal, T., 1985, "The Practice of Amakudari within the Japanese Employment System," Asian Survey, 25, 310.

Brickley, J.A. and C.M. James, 1987, "The Takeover Market, Corporate Board Composition, and Ownership Structure: The Case of Banking," Journal of Law and Economics, 30, 161.

Business Roundtable, 1999, Statement on Corporate Governance. 
Cable, J., 1985, "Capital Market Information and Industrial Performance: The Role of West German Banks," Economic Journal, 95, 118.

Calder, K.E., 1989, "Elites in an Equalizing Role: Ex-Bureaucrats as Coordinators and Intermediaries in the Japanese Government-Business Relationship," Comparative Politics, 21,379 .

CalPERS, 1998, Corporate Governance Core Principles and Guidelines: The United States, www.calpers_governance.org.

Clark, R.C., 1986, Corporate Law, Boston: Little, Brown.

Colignon, R.A., and C. Usui, 2003, Amakudari: The Hidden Fabric of Japan's Economy, Ithaca: Cornell University Press.

Cunningham, Lawrence A., forthcoming 2003, "The Sarbanes-Oxley Yawn: Heavy Rhetoric, Light Reform (And It Might Just Work)," University of Connecticut Law Review, 36.

Dalton, D.R., et al., 1998, "Meta-Analytic Reviews of Board Composition, Leadership Structure, and Financial Performance," Strategic Management Journal, 19, 269.

Demsetz, H. and K. Lehn, 1985, "The Structure of Corporate Ownership," Journal of Political Economy, 93, 1155.

Dore, R.P., 2000, Stock Market Capitalism: Welfare Capitalism -- Japan and Germany versus the Anglo-Saxons, Oxford: Oxford University Press.

Ahmadjian, C.L., 2001, "Changing Japanese Corporate Governance," unpublished.

Ezzamel, M.A. and R. Watson, 1993, "Organizational Form, Ownership Structure and Corporate Performance: A Contextual Empirical Analysis of UK Companies," British Journal of Management, 4, 161.

Fama, Eugene F. 1998. Market Efficiency, Long-term Returns, and Behavioral Finance. Journal of Financial Economics, 49: 283-306.

Fama, E.F. and M.C. Jensen, 1983, "Separation of Ownership and Control," Journal of Law and Economics, 26301.

Gompers, P.A., J.L. Ishii and A. Metrick, 2003, "Corporate Governance and Equity Prices," Quarterly Journal of Economics, 118: 107-55.

Hall, B.J. and D.E. Weinstein, 2000, "Main Banks, Creditor Concentration, and the Resolution of Financial Distress in Japan," in M. Aoki and G.R. Saxonhouse, Finance, Governance, and Competitiveness in Japan, 64, Oxford: Oxford University Press.

Hayashi, F., 2000, "The Main Bank System and Corporate Investment: An Empirical Reassessment," in M. Aoki and G.R. Saxonhouse, Finance, Governance, and Competitiveness in Japan, 81, Oxford: Oxford University Press.

Hermalin, B.E. and M.S. Weisbach, 1998, "Endogenously Chosen Boards of Directors and Their Monitoring of the CEO," American Economic Review, 88, 96-118.

Hermalin, B.E. and M.S. Weisbach, forthcoming, "Boards of Directors as an Endogenously Determined Institution: A Survey of the Economic Literature," FRBNY Economic Policy Review. 
Herman, E.S., 1981, Corporate Control, Corporate Power, Cambridge: Cambridge University Press.

Himmelberg, C.P., R.G. Hubbard, and D. Palia, 1999, "Understanding the Determinants of Managerial Ownership and the Link Between Ownership and Performance," Journal of Financial Economics, 53, 353-84.

Holderness, C.G., R.S. Kroszner, and D.P. Sheehan, 1999, "Were the Good Old Days That Good? Changes in Managerial Stock Ownership since the Great Depression," Journal of Finance, $54,435-469$.

Horiuchi, A. and K. Shimizu, 2001, "Did Amakudari Undermine the Effectiveness of Regulator Monitoring in Japan?," Journal of Banking and Finance, 25, 573.

Hoshi, T., 1998, "Japanese Corporate Governance as a System," in K.J. Hopt, et al., eds., Comparative Corporate Governance: The State of the Art and Emerging Research, 847, Oxford: Oxford University Press.

Hutchinson, M., 2002, "An Analysis of the Association Between Firms' Investment Opportunities, Board Composition, and Firm Performance," unpublished.

Japan Corporate Governance Forum, 1998, Koporeeto gabanansu gensoku [Principles of Corporate Governance], www.jcgf.org/jp.

Japan Corporate Governance Report, 2003, "Interview," Japan Corporate Governance Report (Michael Solomon Associates, Inc.), Jan. 2003, p. 2.

Jensen, M. and J. Warner, 1988, "The Distribution of Power Among Corporate Managers, Shareholders, and Directors," Journal of Financial Economics, 20, 3.

Kaplan, S.N. and B.A. Minton, 1994, "Appointments of Outsiders to Japanese Boards: Determinants and Implications for Managers," Journal of Financial Economics, 36, 225.

Kaplan, S.N., 1994, "Top Executive Rewards and Firm Performance: A Comparison of Japan and the United States," Journal of Political Economy 102, 510.

Kesner, I.F., 1987, "Directors' Stock Ownership and Organizational Performance: An Investigation of Fortune 500 Companies," Journal of Management, 13, 499.

Kester, W.C., 1993, "Banks in the Board Room: Japan, Germany, and the United States," in S.L. Hayes, III, ed., Financial Services: Perspectives and Challenges, 65, Boston: Harvard Business School Press.

Klein, A., 1998, "Firm Performance and Board Committee Structure," Journal of Law and Economics, 41, 275.

Kosei torihiki iinkai, ed., 1994, Kosei torihiki iinkai nenji hokoku [Fair Trade Commission Annual Report], Tokyo: Kosei torihiki iinkai.

Kostant, P.C., 2002, "Team Production and the Progressive Corporate law Agenda," U.C. Davis Law Review, 35, 667.

Mayers, D., A. Shivdasani and C.W. Smith, Jr., 1997, "Board Composition and Corporate Control: Evidence from the Insurance Industry," Journal of Business, 70, 33. 
Milhaupt, C.J. and M. West, 2003, "Institutional Change and M\&A in Japan: Diversity through Deals," in C.J. Milhaupt, ed., Global Markets, Domestic Institutions: Corporate Law and Governance in a New Era of Cross-Border Deals, New York: Columbia University Press, forthcoming.

Milhaupt, C.J., and M.D. West, 2000, "The Dark Side of Private Ordering: An Institutional and Empirical Analysis of Organized Crime," University of Chicago Law Review, 67, 41-97.

Miwa, Y. and J.M. Ramseyer, 2002a, "Banks and Economic Growth: Implications from Japanese History," Journal of Law and Economics, 45, 127-64.

Miwa, Y. and J.M. Ramseyer, 2002b, "The Fable of the Keiretsu," Journal of Economics and Management Strategy, 11, 169-224.

Miwa, Y. and J.M. Ramseyer, 2002c, "The Myth of the Main Bank: Japan and Comparative Corporate Governance," Law and Social Inquiry, 27, 401-24.

Miwa, Y. and J.M. Ramseyer, 2003a, "Does Ownership Matter? Evidence from the Zaibatsu Dissolution Program," Journal of Economics and Management Strategy, 12, 67-89.

Miwa, Y. and J.M. Ramseyer, 2003b, "Financial Malaise and the Myth of the Misgoverned Bank," in in C.J. Milhaupt, ed., Global Markets, Domestic Institutions: Corporate Law and Governance in a New Era of Cross-Border Deals, New York: Columbia University Press, pp. 339-72.

Miwa, Y. and J.M. Ramseyer, 2003c, "Does Relationship Banking Matter? Japanese BankBorrower Ties in Good Times and Bad," Center for International Research in the Japanese Economy, Discussion Paper CIRJE-F-239, August 2003, University of Tokyo Faculty of Economics.

Miwa, Y. and J.M. Ramseyer, 2003d, Conflicts of Interest in Japanese Insolvencies: The Problem of Bank Rescues,"Harvard Law School John M. Olin Center for Law, Economics \& Business Discussion Paper No. 435..

Miwa, Y. and J.M. Ramseyer, 2004a, "Directed Credit? The Loan Market in High-Growth Japan," Journal of Economics and Mgmt Strategy, forthcoming.

Miwa, Y., 1998, "Torishimari yaku kai to torishimari yaku [Boards of Directors and Directors]," in Y. Miwa, et al., eds., Kaisha ho no keizaigaku [The Economics of Corporate Law], 89, Tokyo: University of Tokyo Press.

Monks, R.A.G. and N. Minow, 1995, Corporate Governance, Oxford: Blackwell.

Morck, R., A. Shleifer, and R.W. Vishny, 1988, "Management Ownership and Market Valuation: An Empirical Analysis," Journal of Financial Economics, 20, 293-315.

Morck, R., M. Nakamura, and A. Shivdasani, 2000, "Banks, Ownership Structure, and Firm Value in Japan," Journal of Business, 73, 539.

Myers, S.C., 2001, "Capital Structure," Journal of Economic Perspectives, 15(2), 81.

Nihon shoken keizai kenkyu jo, ed., as updated, Kabushiki toshi shueki ritsu [Rates of Return on Common Stocks], Tokyo: Nihon shoken keizai kenkyu jo.

Nikkei QUICK joho, K.K., as updated, NEEDS, Tokyo, Nikkei QUICK joho. 
Nikkei QUICK joho, K.K., as updated, QUICK, Tokyo, Nikkei QUICK joho.

NYSE Corporate Accountability and Listing Standards Committee, Report, June 6, 2002.

Okimoto, D.I., 1989, Between MITI and the Market: Japanese Industrial Policy for High Technology, Stanford: Stanford University Press.

Romano, R., 1991, "The Shareholder Suit: Litigation without Foundation?," Journal of Law, Economics and Organization, 7, 55.

Romano, R., 1996, "Corporate Law and Corporate Governance," Industrial and Corporate Change, $5,277$.

Romano, R., 2001, "Less is More: Making Institutional Investor Activism a Valuable Mechanism of Corporate Governance," Yale Journal of Regulation, 18, 174.

Schaede, U., 1994, "Understanding Corporate Governance in Japan: Do Classical Concepts Apply?," Industrial and Corporate Change, 3, 285.

Schaede, U., 1995, "The 'Old Boy' Network and Government-Business Relationship in Japan," Journal of Japanese Studies, 21, 293.

Sheard, P., 1994, "Reciprocal Delegated Monitoring in the Japanese Main Bank System," Journal of Japanese and International Economies, 8, 1.

Sheard, P., 1996, "Banks, Blockholders and Corporate Governance: The Role of External Appointees to the Board," in P. Sheard, ed., Japanese Firms, Finance and Markets, 181, Melbourne: Addison-Wesley.

Stock, J.H. and M.W. Watson, 2003, Introduction to Econometrics, Boston: Addison-Wesley.

TIAA-CREF, 2000, Policy Statement on Corporate Governance, www.tiaacref.org/libra/governance.

Toyo keizai, ed., as updated, Kigyo keiretsu soran [Firm Keiretsu Overview], Tokyo: Toyo keizai.

Toyo keizai, relevant issues, Kaisha shikiho [Seasonal Corporate News], Tokyo: Toyo keizai.

van Rixtel, A.A.R.J.M. and W.H.J. Hassink, "Monitoring the Monitors: Are Old Boys Networks Being Used to Monitor Japanese Private Banks?," Journal of Japanese and International Economies, 16, 1.

van Wolferen, K., 1989, The Enigma of Japanese Power, New York: Vantage.

van Rixtel, Adrian, 2002, Informality and Monetary Policy in Japan: The Political Economy of Bank Performance, Cambridge: Cambridge University Press.

Vance, S.C., 1978, "Corporate Governance: Assessing Corporate Performance by Boardroom Attributes," Journal of Business Research, 6, 203.

Weinstein, D.E., and Yishay Yafeh, 1998, "On the Costs of a Bank-Centered Financial System: Evidence from the Changing Main Bank Relations in Japan," Journal of Finance, 53, 63572.

West, M.D., 2001, “Why Shareholders Sue: The Evidence from Japan,” Journal of Legal Studies, 30,351 . 
Woodall, B., 1996, Japan Under Construction: Corruption, Politics, and Public Works, Berkeley: University of California Press, 1996. 